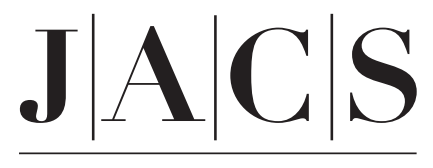

A R T I C L E S

Published on Web 03/29/2002

\title{
Self-Complementarity of Oligo-2-aminopyridines: A New Class of Hydrogen-Bonded Ladders
}

\author{
Man-kit Leung, ${ }^{,}, \dagger$ Ashis B. Mandal, ${ }^{\dagger}$ Chih-Chieh Wang, ${ }^{\ddagger}$ Gene-Hsiang Lee, ${ }^{\dagger}$ \\ Shie-Ming Peng, ${ }^{*,+}$ Hsing-Ling Cheng, ${ }^{\dagger}$ Guor-Rong Her, ${ }^{\dagger}$ Ito Chao, ${ }^{*}$, Hsiu-Feng Lu, ${ }^{,}$ \\ Ying-Chieh Sun," Mei-Ying Shiao, ${ }^{\perp}$ and Pi-Tai Chou ${ }^{*, \dagger}$ \\ Contribution from the Department of Chemistry, National Taiwan University, \\ Taipei 106, Taiwan, Department of Chemistry, Soochow University, Taipei, Taiwan, \\ Institute of Chemistry, Academia Sinica, Taipei, Taiwan, Department of Chemistry, \\ National Taiwan Normal University, Taipei, Taiwan, and Department of Chemistry, \\ National Chung Cheng University, Chia Yi, Taiwan
}

Received July 10, 2001. Revised Manuscript Received November 15, 2001

\begin{abstract}
A new class of hydrogen-bonded ladders based on hydrogen-bonded dimerization of oligo- $\alpha$ aminopryidines has been demonstrated. Jorgensen's model can be successfully applied to this hydrogenbonding system in nonpolar solvents. The results show the competitive enthalpy/entropy compensation relationship upon dimerization. Although increasing the number of hydrogen-bonding interactions would enhance the hydrogen-bonding stabilization enthalpy, this stabilization enthalpy per unit would be partially sacrificed to compensate for the entropy loss due to dimerization. These results clearly support the importance of preorganization in designing hydrogen-bonding guest-host molecules.
\end{abstract}

\section{Introduction}

The construction of molecules that associate in a strong, directional, and selective mode is a challenging topic in supramolecular chemistry. Because hydrogen bonds are relatively flexible in geometry as compared to rigid covalent bonds, the principle of using hydrogen bonds to confer binding strength and selectivity has become an important topic for research. ${ }^{1,2}$ Many examples of using hydrogen-bonding interactions to control the self-assembling of molecules into well-defined aggregates, ranging from container molecules, ${ }^{3}$ supramolecular tubes ${ }^{4}$ to

* To whom correspondence should be addressed. E-mail: P.-T.C., chop@ccms.ntu.edu.tw; M.-k.L., mkleung@ms.cc.ntu.edu.tw; S.-M.P., smpeng@mail.ch.ntu.edu.tw.

National Taiwan University.

$\doteqdot$ Soochow University.

$\S$ Academia Sinica.

"National Taiwan Normal University.

$\perp$ National Chung Cheng University.

(1) For recent reviews, see: (a) Prins, L. J.; Reinhoudt, D. N.; Timmerman, P. Angew. Chem., Int. Ed. 2001, 40, 2382. (b) Zimmerman, S. C.; Corbin, P. S. Struct. Bonding 2000, 96, 63. (c) Niemz, A.; Rotello, V. M. Acc. Chem. Res. 1999, 32, 44. (d) Ward, M. D. Chem. Soc. Rev. 1997, 26, 365. (e) Doronina, S. O.; Behr, J. P. Chem. Soc. Rev. 1997, 26, 63. (f) Fyfe, M. C. T.; Stoddart, J. F. Acc. Chem. Res. 1997, 30, 393.

(2) For examples, see: (a) Corbin, P. S.; Zimmerman, S. C. J. Am. Chem. Soc. 2000, 122, 3779. (b) Zeng, H.; Miller, R. S.; Flowers, R. A., II; Gong, B. J. Am. Chem. Soc. 2000, 122, 2635. (c) Appella, D. H.; Barchi, J. J., Jr.; Durell, S. R.; Gellman, S. H. J. Am. Chem. Soc. 1999, 121, 2309. (d) Ranganathan, A.; Pedireddi, V. R.; Rao, C. N. R. J. Am. Chem. Soc. 1999, 121, 1752. (e) Kuduva, S. S.; Craig, D. C.; Nangia, A.; Desiraju, G. R. J. Am. Chem. Soc. 1999, 121, 1936. (f) Marfurt, J.; Leumann C. Angew. Chem., Int. Ed. 1998, 37, 175. (g) Coe, S.; Kane, J. J.; Nguyen, T. L.; Toledo, L. M.; Wininger, E.; Fowler, F. W.; Lauher, J. W. J. Am. Soc. Chem. 1997, 119, 86.

(3) (a) Castellano, R. K.; Nuckolls, C.; Rebek, J., Jr. J. Am. Chem. Soc. 1999, 121, 11156. (b) Schalley, C. A.; Martín, T.; Obst, U.; Rebek, J., Jr. J. Am. Chem. Soc. 1999, 121, 2133. (c) Vysotsky, M. O.; Pop, A.; Broda, F.; Thondorf, I.; Bohmer, V. Chem.-Eur. J. 2001, 7, 4403.

(4) Baumeister, B.; Matile, S. Chem.-Eur. J. 2000, 6, 1739.

10.1021/ja011679p CCC: $\$ 22.00$ @ 2002 American Chemical Society artificial ion channels, ${ }^{5}$ have been reported during the past decade. In addition, the principle of hydrogen-bonding interactions has also been applied to crystal engineering. ${ }^{6}$ This requires self-recognition between identical molecules, a much less common phenomenon usually restricted to molecules containing "complementary donor and acceptor units". Recently, using the hydrogen-bond array, instead of covalent bonds, to construct zipperic ladder molecules has been explored. ${ }^{7,8}$ Polymeric structure $\mathbf{1}$ intrigues us because $\mathbf{1}$ may dimerize to form a belt-shape zipperic dimer through hydrogen-bonding interactions. Because 1 contains an alternating proton donor/acceptor sequence, according to Jorgensen's theory, ${ }^{9}$ a relatively strong secondary repulsive interaction is expected. This would lead to a relatively small hydrogen-bonding stabilization arising from each of the repeating units. The prediction is particularly attractive to us

(5) (a) Sakai, N.; Brennan, K. C.; Weiss, L. A.; Matile, S. J. Am. Chem. Soc. 1997, 119, 8726. (b) Sakai, N.; Matile, S. Chem.-Eur. J. 2000, 6, 1731.

(6) MacDonald, J. C.; Whitesides, G. M. Chem. Rev. 1994, 94, 2383.

(7) For recent reviews, see: (a) Piguet, C.; Bernardinelli, G.; Hopfgartner, G. Chem. Rev. 1997, 97, 2005. (b) Rebek, J., Jr. Chem. Soc. Rev. 1996, 255. (c) Whitesides, G. M.; Simanek, E. E.; Mathias, J. P.; Seto, C. T.; Chin, D. N.; Mammen, M.; Gordon, D. M. Acc. Chem. Res. 1995, 28, 37.

(8) For recent examples, see: (a) Corbin, P. S.; Zimmerman, S. C.; Thiessen, P. A.; Hawryluk, N. A.; Murray, T. J. J. Am. Chem. Soc. 2001, 123, 10475. (b) Archer, E. A.; Sochia, A. E.; Krische, M. J. Chem.-Eur. J. 2001, 7, 2049. (c) Söntjens, S. H. M.; Sijbesma, R. P.; van Genderen, M. H. P.; Meijer, E. W. J. Am. Chem. Soc. 2000, 122, 7487. (d) Archer, E A.; Goldberg, N. T.; Lynch, V.; Krische, M. J. J. Am. Chem. Soc. 2000 , 122, 5006. (e) Bisson, A. P.; Carver, F. J.; Eggleston, D. S.; Haltiwanger, R. C.; Hunter, C. A.; Livingstone, D. L.; McCabe, J. F.; Rotger, C.; Rowan, A. E. J. Am. Chem. Soc. 2000, 122, 8856. (f) Folmer, B. J. B.; Sijbesma, R. P.; Kooijman, H.; Spek, A. L.; Meijer, E. W. J. Am. Chem. Soc. 1999, 121, 9001. (g) Sakai, N.; Majumdar, N.; Matile, S. J. Am. Chem. Soc. 1999, 121, 4294. (h) Sessler, J. L.; Wang, R. Angew. Chem. Int. Ed. 1998, 37, 1726. (i) Bisson, A. P.; Carver, F. J.; Hunter, C. A.; Waltho, J. P. J. Am. Chem. Soc. 1994, 116, 10292. (j) Ghadiri, M. R.; Granja, J. R.; Milligan, R. A.; McRee, D. E.; Khazanovich, N. Nature 1993, 366,324 .

J. AM. CHEM. SOC. 2002, 124, 4287-4297 4287 
Scheme 1
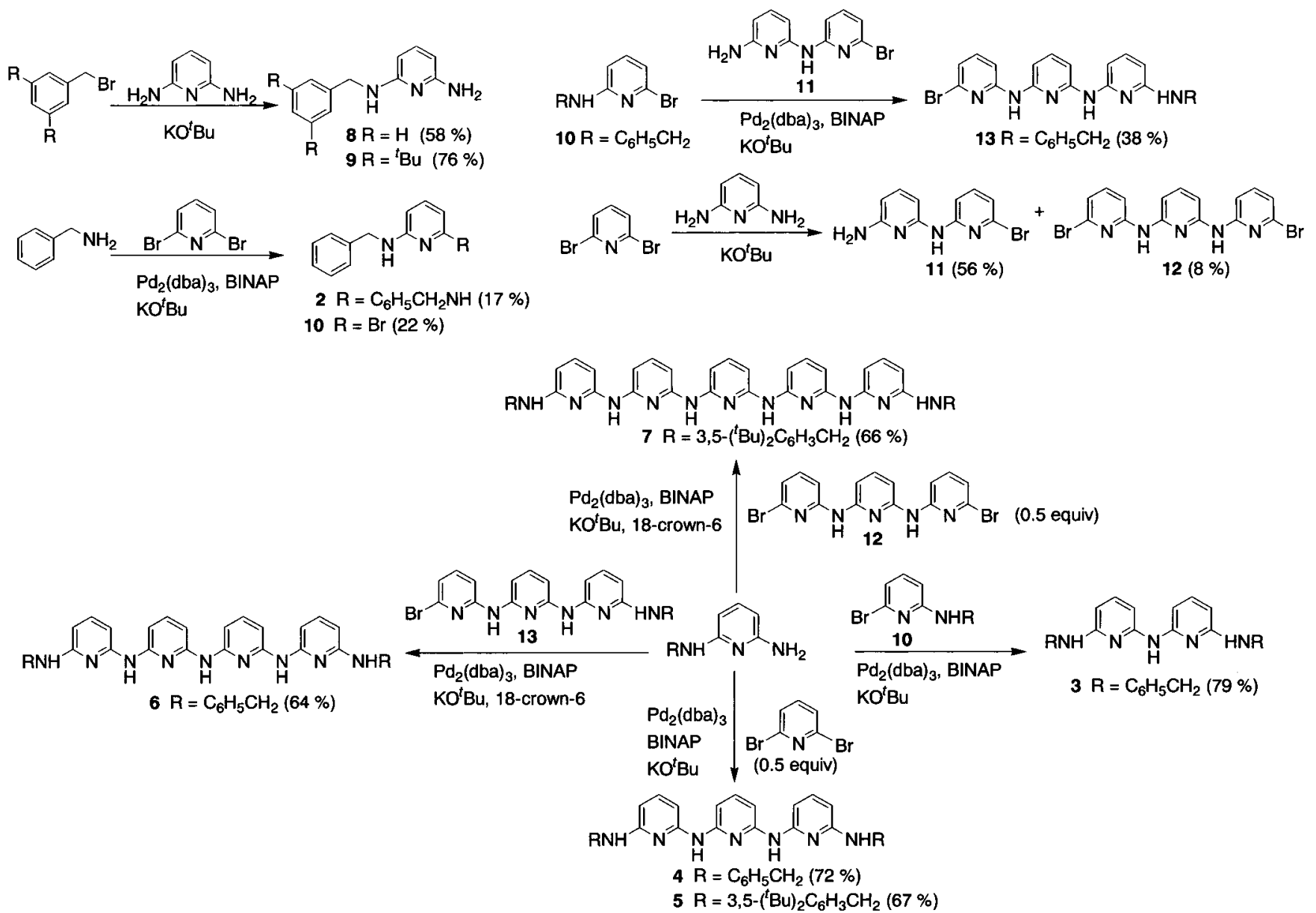

because a relatively low dissociation energy barrier for the zipperic dimer would be expected. This implies a fast association-dissociation process that may be beneficial for $\mathbf{1}$ to search for the optimal matching, resulting in the most stable dimeric pair.

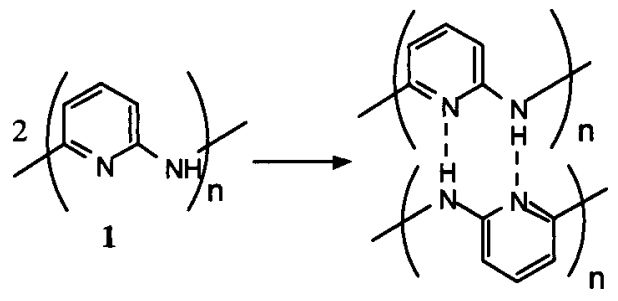

To evaluate the dimerization behavior of $\mathbf{1}$, the dimerization behavior of its oligomers $\mathbf{2 - 7}$ is investigated. Through a systematic study of the structure of their zipperic hydrogenbonded dimers in solid state as well as their thermodynamics upon hydrogen-bonded dimerization in the solution phase, valuable information can be provided about the self-dimerization process. In addition, this study provides a systematic way to evaluate the Jorgensen's theory, an important model for the quantitative prediction of hydrogen-bonding interactions.

(9) (a) Zimmerman, S. C.; Murray, T. J. Tetrahedron Lett. 1994, 35, 4077; 1995, 36, 7627. (b) Murray, T. J.; Zimmerman, S. C. J. Am. Chem. Soc. 1992, 114, 4010. (c) Pranata, J.; Wierschke, S. G.; Jorgensen, W. L. J. Am. Chem. Soc. 1991, 113, 2810. (d) Jorgensen, W. L.; Pranata, J. J. Am. Chem. Soc. 1990, 112, 2008.

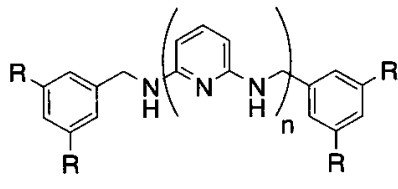

$2 \mathrm{R}=\mathrm{H}, \mathrm{n}=1 \quad 3 \mathrm{R}=\mathrm{H}, \mathrm{n}=2$

$4 \mathrm{R}=\mathrm{H}, \mathrm{n}=3 \quad 5 \mathrm{R}=t-\mathrm{Bu}, \mathrm{n}=3$

$6 \mathrm{R}=\mathrm{H}, \mathrm{n}=4 \quad 7 \mathrm{R}=t-\mathrm{Bu}, \mathrm{n}=5$

\section{Results and Discussion}

2.1. Tactic for the Synthesis of 2-7. Syntheses of $\mathbf{2}$ and $\mathbf{8}$ have been reported in the literature.$^{10}$ Oligomers $3-\mathbf{7}$, and their precursors, were prepared on the basis of the Buchwald's palladium-catalyzed amination procedures (Scheme 1). ${ }^{11}$ To construct the target molecules, terminal building blocks $\mathbf{8}$ and the di-tert-butyl substituted 9 were prepared from benzylation of 2,6-diaminopyridine. Terminal di-tert-butyl substituted 9 was used as the precursor for $\mathbf{5}$ and $\mathbf{7}$ because it could enhance the solubility ${ }^{12}$ of $\mathbf{5}$ and $\mathbf{7}$. The solubility criterion is particularly important in the measurements of the dimerization constant. Compound $\mathbf{1 0}$ was obtained from palladium-catalyzed monoam-

(10) (a) Sprinzak, Y. J. Am. Chem. Soc. 1956, 78, 3207. (b) Czuba, W. Kowalski, P. Pol. J. Chem. 1980, 54, 853.

(11) (a) Wagaw, S.; Buchwald, S. L. J. Org. Chem. 1996, 61, 7240. (b) Lai, S.-Y.; Lin, T.-W.; Chen, Y.-H.; Wang, C.-C.; Lee, G.-H.; Yang, M.-h.; Leung, M.-k; Peng, S.-M. J. Am. Chem. Soc. 1999, 121, 250. (c) Yang, M.-H.; Lin, T.-W.; Chou, C.-C.; Lee, H.-C.; Chang, H. C.; Lee, G.-H Leung, M-.k.; Peng, S.-M. Chem. Commun. 1997, 2279.

(12) Schenk, R.; Gregorius, H.; Meerholz, K.; Heinze, J.; Müllen, K. J. Am Chem. Soc. 1991, 113, 2634. 
Table 1. Crystallographic Data for $2 a, 2 b, 3$, and 4

\begin{tabular}{|c|c|c|c|c|}
\hline & $2 a$ & $2 b$ & 3 & 4 \\
\hline chemical formula & $\mathrm{C}_{19} \mathrm{H}_{19} \mathrm{~N}_{3}$ & $\mathrm{C}_{19} \mathrm{H}_{19} \mathrm{~N}_{3}$ & $\mathrm{C}_{24} \mathrm{H}_{23} \mathrm{~N}_{5}$ & $\mathrm{C}_{29} \mathrm{H}_{27} \mathrm{~N}_{7}$ \\
\hline formula weight & 289.37 & 289.37 & 381.47 & 473.58 \\
\hline space group & $P 2 / c$ & $P 2_{1}$ & $P 2_{1} / c$ & $C 2 / c$ \\
\hline$a(\AA)$ & $17.0899(3)$ & $12.9834(5)$ & $14.5143(3)$ & $18.7696(4)$ \\
\hline$b(\AA)$ & $9.0332(1)$ & $5.6602(2)$ & $19.6482(4)$ & $12.1599(20$ \\
\hline$c(\AA)$ & $15.8559(1)$ & $21.9238(7)$ & $14.7183(3)$ & $21.8358(5)$ \\
\hline$\beta\left({ }^{\circ}\right)$ & $102.860(1)$ & $100.692(1)$ & $99.308(2)$ & $98.384(1)$ \\
\hline$V\left(\AA^{3}\right)$ & $2386.38(5)$ & $1583.2(1)$ & $4142.1(2)$ & $4930.5(2)$ \\
\hline$Z$ & 6 & 4 & 8 & 8 \\
\hline$F(000)$ & 924 & 616 & 1616 & 2000 \\
\hline$T(\mathrm{~K})$ & $295(2)$ & $295(2)$ & $295(2)$ & $295(2)$ \\
\hline$\lambda(\mathrm{Mo} \mathrm{K} \alpha)(\AA)$ & 0.71073 & 0.71073 & 0.71073 & 0.71073 \\
\hline$D_{\text {calc }}\left(\mathrm{kg} \mathrm{m}^{-3}\right)$ & 1.208 & 1.214 & 1.223 & 1.276 \\
\hline$\mu\left(\mathrm{mm}^{-1}\right)$ & 0.073 & 0.073 & 0.075 & 0.079 \\
\hline reflection collected & 17892 & 6396 & 25990 & 25402 \\
\hline unique reflections & 4217 & 4529 & 7296 & 4346 \\
\hline absorption correction & $\begin{array}{l}\text { semiempirical from } \\
\text { equivalents }\end{array}$ & $\begin{array}{l}\text { semiempirical from } \\
\text { equivalents }\end{array}$ & $\begin{array}{l}\text { semiempirical from } \\
\text { equivalents }\end{array}$ & $\begin{array}{l}\text { semiempirical from } \\
\text { equivalents }\end{array}$ \\
\hline refinement on & $F^{2}$ & $F^{2}$ & $F^{2}$ & $F^{2}$ \\
\hline parameters refined & 312 & 414 & 548 & 342 \\
\hline$R\left(F_{\mathrm{o}}\right)^{a}(I>2 \sigma(I))$ & 0.0763 & 0.0583 & 0.0611 & 0.0796 \\
\hline$R_{\mathrm{w}}\left(F_{\mathrm{o}}^{2}\right)^{b}(I>2 \sigma(I))$ & 0.1785 & 0.1067 & 0.1188 & 0.1410 \\
\hline$R\left(F_{\mathrm{O}}\right)^{a}$ (all data) & 0.1479 & 0.0912 & 0.1349 & 0.1338 \\
\hline$R_{\mathrm{W}}\left(F_{\mathrm{o}}^{2}\right)^{b}$ (all data) & 0.2195 & 0.1236 & 0.1500 & 0.1858 \\
\hline $\mathrm{GOF}$ on $F^{2}$ & 1.002 & 1.106 & 1.055 & 1.222 \\
\hline
\end{tabular}

${ }^{a} R\left(F_{\mathrm{o}}\right)=\sum|| F_{\mathrm{o}}|-| F_{\mathrm{c}}\left|/ \sum\right| F_{\mathrm{o}} \mid \cdot{ }^{b} R_{\mathrm{w}}\left(F_{\mathrm{o}}{ }^{2}\right)=\left[\sum\left\{\mathrm{w}\left(F_{\mathrm{o}}{ }^{2}-F_{\mathrm{c}}{ }^{2}\right)^{2}\right\} / \sum\left\{\mathrm{w}\left(F_{\mathrm{o}}{ }^{2}\right)^{2}\right\}\right]^{1 / 2}$.

ination of 2,6-dibromopyridine. The internal building blocks 11 and $\mathbf{1 2}$ were obtained from a base-catalyzed coupling reaction of a 1:1 ratio of 2,6-dibromopyridine and 2,6-diaminopyridine. Although 12 is expected to be a minor product in our reaction conditions, it could be easily isolated by precipitation in $\mathrm{CH}_{2} \mathrm{Cl}_{2}$ due to the relatively low solubility of $\mathbf{1 2}$. The residue was then concentrated and subjected to liquid chromatography on silica gel to give $\mathbf{1 1}$ as a pure product. Palladium-catalyzed Buchwald's coupling of $\mathbf{1 0}$ with $\mathbf{1 1}$ would afford another building block $\mathbf{1 3}$ in a $38 \%$ yield. On the other hand, $\mathbf{1 2}$ was used as an important block for the synthesis of 7. Once the terminal and the internal building blocks were in hand, oligomers 3-7 were synthesized from the corresponding building blocks using normal Buchwald's coupling conditions. However, addition of 18-crown- 6 was required in the synthesis of 6 and 7 to facilitate the coupling reaction. ${ }^{13}$ Details of syntheses and spectral characterization are described in the following sections and in the Experimental Section.

2.2. Single-Crystal X-ray Crystallographic Analyses of 2-4. Single crystals of 2-4 were easily prepared by slow evaporation of the solvent, and their crystallographic data are summarized in Table 1. Unfortunately, attempts at preparation of the single crystals of 5-7 were unsuccessful. Intermolecular hydrogen-bonding interactions were observed in the crystal forms of compounds $\mathbf{2 - 4}$, of which the hydrogen-bond parameters are summarized in Table 2.

Two crystallization patterns by the molecular aggregation of $\mathbf{2}$ are observed; one is a trimeric form $\mathbf{2 a}$ (Figure 1), and the other is a zigzag polymeric chain $\mathbf{2 b}$ (Figure 2). The $\mathbf{2 a}$ form is $P 2 / c$ with $Z=6$ in which an interesting trimer sharing four hydrogen bonds with a 2-fold axis through the $\mathrm{N}(5), \mathrm{C}(22)$ atoms is found (Figure 1a). The nitrogen atom N(5) of the central pyridine is symmetrically hydrogen bonded to two amino groups $\mathrm{N}(3)$ and $\mathrm{N}(3 \mathrm{~A})$ of two other diaminopyridine molecules

(13) Wolfe, J. P.; Buchwald, S. L. J. Org. Chem. 1997, 62, 6066.
Table 2. Geometrical Parameters for $\mathrm{N}-\mathrm{H} \cdots \mathrm{N}$ Hydrogen Bonds Observed in the Crystal Lattices of $\mathbf{2 a}, \mathbf{2} \mathbf{b}, \mathbf{3}$, and $\mathbf{4}$

\begin{tabular}{cllll}
\hline crystal & \multicolumn{1}{c}{$\mathrm{H}$-bond $(\AA)$} & $\mathrm{D} \cdots \mathrm{A}(\AA)$ & $\mathrm{H} \cdots \mathrm{A}(\AA)$ & $\angle \mathrm{D}-\mathrm{H} \cdots \mathrm{A}\left({ }^{\circ}\right)$ \\
\hline $\mathbf{2 a}$ & $\mathrm{N}(3)-\mathrm{H}(3) \cdots \mathrm{N}(5)$ & $3.137(5)$ & $2.21(3)$ & $160(1)$ \\
& $\mathrm{N}(4)-\mathrm{H}(4) \cdots \mathrm{N}(2)$ & $3.008(5)$ & $2.20(3)$ & $158(1)$ \\
& mean & 3.07 & 2.21 & 159 \\
$\mathbf{2 b}$ & $\mathrm{N}(1)-\mathrm{H}(1) \cdots \mathrm{N}(2)$ & $3.207(5)$ & $2.54(4)$ & $146(1)$ \\
& $\mathrm{N}(4)-\mathrm{H}(4) \cdots \mathrm{N}(5)$ & $3.170(5)$ & $2.32(4)$ & $147(1)$ \\
& mean & 3.19 & 2.43 & 147 \\
$\mathbf{3}$ & $\mathrm{N}(3)-\mathrm{H}(3) \cdots \mathrm{N}(7)$ & $3.022(5)$ & $2.08(3)$ & $178(1)$ \\
& $\mathrm{N}(5)-\mathrm{H}(5) \cdots \mathrm{N}(9)$ & $3.118(5)$ & $2.16(4)$ & $167(1)$ \\
& $\mathrm{N}(6)-\mathrm{H}(6) \cdots \mathrm{N}(2)$ & $3.071(5)$ & $2.16(3)$ & $169(1)$ \\
& $\mathrm{N}(8)-\mathrm{H}(8) \cdots \mathrm{N}(4)$ & $3.019(5)$ & $2.09(3)$ & $177(1)$ \\
& mean & 3.06 & 2.12 & 173 \\
$\mathbf{4}$ & $\mathrm{N}(1)-\mathrm{H}(1) \cdots \mathrm{N}(6)$ & $3.014(6)$ & $2.15(4)$ & $170(1)$ \\
& $\mathrm{N}(3)-\mathrm{H}(3) \cdots \mathrm{N}(4)$ & $3.025(6)$ & $2.21(4)$ & $166(1)$ \\
& $\mathrm{N}(5)-\mathrm{H}(5) \cdots \mathrm{N}(2)$ & $3.089(6)$ & $2.15(4)$ & $166(1)$ \\
& mean & 3.04 & 2.17 & 167 \\
& & & & \\
\end{tabular}

(dashed line). On the other hand, the amino groups of the central molecule $\mathrm{N}(4)$ and $\mathrm{N}(4 \mathrm{~A})$ are bonded to the nitrogen atom of pyridine of the other two diaminopyridine molecules $\mathrm{N}(2)$ and $\mathrm{N}(2 \mathrm{~A})$ (dashed line). The $\mathrm{N} \cdots \mathrm{N}$ distances are found to be $3.173(5)$ and $3.008(5) \AA$ for $\mathrm{N}(3) \cdots \mathrm{N}(5)$ and $\mathrm{N}(4) \cdots \mathrm{N}(2)$ hydrogen bonds, respectively. The hydrogen-bond $\mathrm{H} \cdots \mathrm{N}$ distances of $2.21(3) \AA$ for $\mathrm{N}(3)-\mathrm{H}(3) \cdots \mathrm{N}(5)$ and $\mathrm{N}(3 \mathrm{~A})-\mathrm{H}(3 \mathrm{~A}) \cdots \mathrm{N}(5)$ are slightly longer than those of $2.20(3)$ $\AA$ for $\mathrm{N}(4)-\mathrm{H}(4) \cdots \mathrm{N}(2)$ and $\mathrm{N}(4 \mathrm{~A})-\mathrm{H}(4 \mathrm{~A}) \cdots \mathrm{N}(2 \mathrm{~A})$. Another $3-\mathrm{D}$ picture of $2 \mathbf{a}$ depicted in Figure $1 \mathrm{~b}$ clearly displays the spatial arrangement among these trimers.

The second form $\mathbf{2 b}$ is $P 2_{1}$ with $Z=4$ (Figure 2). Two crystallographic independent, one-dimensional zigzag hydrogen-bonding networks are found in this structure. Two chains are parallel to the $b$ axis with different orientations. In one chain, one amino group $\mathrm{N}(1)-\mathrm{H}(1)$ is hydrogen bonded to the pyridine $\mathrm{N}(2 \mathrm{~A})$ of the next layer. A similar bonding pattern also occurs in the other chain, in which $\mathrm{N}(4)-\mathrm{H}(4)$ is hydrogen bonded to the pyridine $\mathrm{N}(5 \mathrm{~A})$ of the next layer. The presence of the hydrogen bonds aligns the benzene ring and 

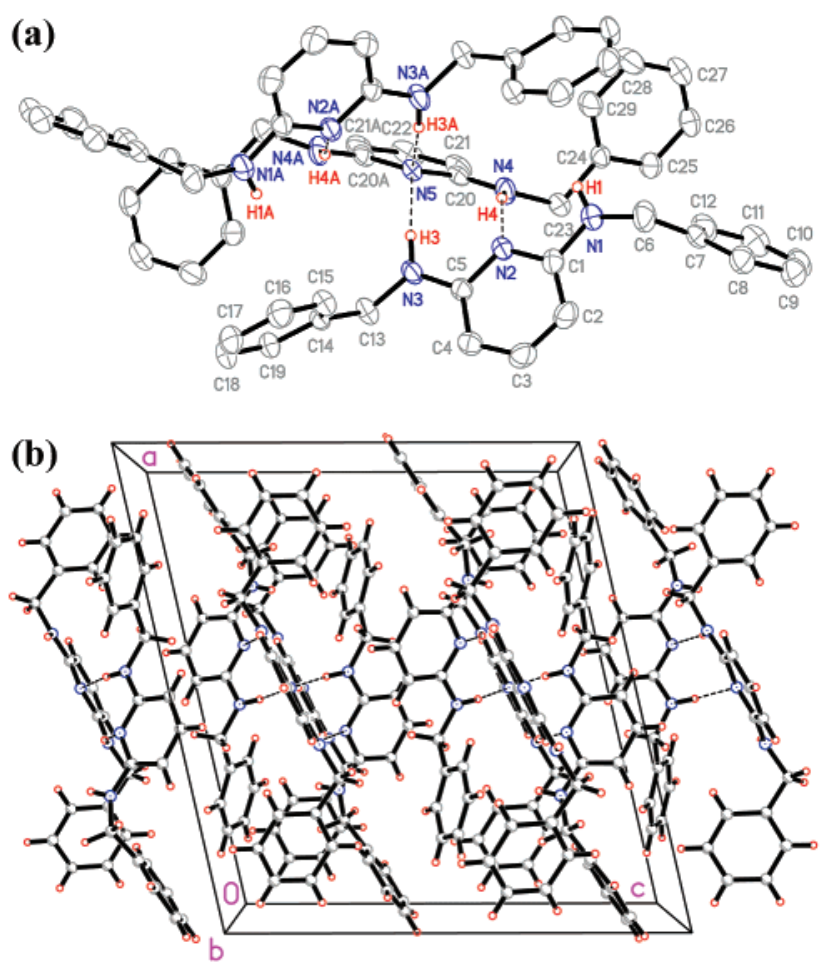

Figure 1. (a) The molecular structure of $\mathbf{2}$ in a trimeric form. Ellipsoids are drawn at the $30 \%$ probability level. (b) Perspective view of 2a along the crystallographic $b$ axis.

pyridine ring of $\mathbf{2}$ packed in an orderly arrangement (Figure $2 b$ ), where the interlayer distance is equal to the length of the $b$ axis $(5.660 \AA)$. The $\mathrm{N}(1) \cdots \mathrm{N}(2 \mathrm{~A})$ and $\mathrm{N}(4) \cdots \mathrm{N}(5 \mathrm{~A})$ distances are found to be 3.207(5) and 3.170(5) $\AA$, respectively. The relatively long hydrogen-bond $\mathrm{H} \cdots \mathrm{N}$ distances of 2.54(4) and 2.32(4) $\AA$ for $\mathrm{N}(1)-\mathrm{H}(1) \cdots \mathrm{N}(2 \mathrm{~A})$ and $\mathrm{N}(4)-\mathrm{H}(4) \cdots \mathrm{N}(5 \mathrm{~A})$ with small bond angles of $146(1)^{\circ}$ and $147(1)^{\circ}$ in $\mathbf{2 b}$ indicate weaker hydrogen-bonding interactions between molecules in comparison to those in $2 \mathbf{2} .{ }^{14} \mathrm{We}$ tentatively attributed this observation to the lower hydrogenbonding density in $\mathbf{2 b}$, in which only one pair of hydrogen bond per molecule was formed. However, the existence of two forms of diaminopyridine in the solid state indicates that the two kinds of hydrogen-bonding network may only slightly differ in their free energy.

Compounds 3 and $\mathbf{4}$ crystallize in a spiral conformation of the dimeric form possessing four and six pairs of $\mathrm{N}-\mathrm{H} \cdots \mathrm{N}$ hydrogen bonds, respectively, which are shown in Figures 3 and 4. Triaminodipyridine 3 crystallizes in $P 2_{1} / c$ with $Z=8$. There is one helical dimer in an asymmetric unit (Figure 3). Four pairs of hydrogen bonds form between the amino groups and the nitrogen atoms of the pyridine groups. Similarly, tetraaminotripyridine 4 crystallizes in $C 2 / c$ with $Z=8$. The helical dimer is located at the crystallographic 2-fold axis in which only one molecule is found in an asymmetric unit (Figure 4). Six pairs of hydrogen bonds form in the dimeric configuration of 4 .

The distances between $\mathrm{NH} \cdots \mathrm{N}$ and $\mathrm{N} \cdots \mathrm{N}$, as well as the $\mathrm{NH} \cdots \mathrm{N}$ angle, are useful parameters for evaluating the hydrogen-

(14) Jeffrey, G. A. An Introduction to Hydrogen Bonding; Oxford: New York, $1997 ;$ p 12 bond interactions. In general, a strong hydrogen-bonding interaction would lead to short $\mathrm{NH} \cdots \mathrm{N}$ and $\mathrm{N} \cdots \mathrm{N}$ distances, and a large $\mathrm{NH} \cdots \mathrm{N}$ angle. ${ }^{14}$ The $\mathrm{N} \cdots \mathrm{N}$ distances vary in a range of $3.019(5)-3.118(5) \AA$ for $\mathbf{3}$ with an average of 3.06 $\AA$, and 3.014(6)-3.089(6) $\AA$ with an average of $3.04 \AA$ for 4 . The $\mathrm{H} \cdots \mathrm{N}$ distances vary in a range of $2.08(3)-2.16(4) \AA$ for 3 with an average of $2.12 \AA$, and $2.15(4)-2.21(4) \AA$ with an average of $2.17 \AA$ for 4 . These values are slightly larger than the reported statistical mean distances of $2.939 \AA(\sigma=$ $0.092)$ for $\mathrm{N} \cdots \mathrm{N}$ and $2.04 \AA(\sigma=0.14)$ for $\mathrm{R}_{2} \mathrm{NH} \cdots \mathrm{N}\left(\mathrm{sp}^{2}\right)$, but still fall within the boundary of standard deviations. ${ }^{15}$ The average $\mathrm{NH} \cdots \mathrm{N}$ angles of $173^{\circ}$ and $167^{\circ}$ for $\mathbf{3}$ and $\mathbf{4}$, respectively, in comparison to the statistical mean of $166^{\circ}$ ( $\sigma$ $=8.7$ ) also suggest reasonably strong intermolecular hydrogenbond interactions.

The distances between the donor nitrogen atoms and between the acceptor nitrogen atoms of the proximal hydrogen-bond donor-acceptor pairs are of particular importance because the secondary interactions arising from those atoms strongly affect the stability of the dimers. Data listed in Table 3 show an average $\mathrm{N}-\mathrm{N}$ separation of $3.72 \AA$ for the dimer of $\mathbf{3}$ and 3.69 $\AA$ for the dimer of 4 . Because these distances are still short, substantial electrostatic interactions are expected. ${ }^{9 c}$

2.3. Thermodynamics of Dimerization. The possibility of the formation of hydrogen-bonded dimers in solution was first evaluated by electrospray ionization mass spectroscopy (ESIMS). ${ }^{16}$ Although mass spectrometry only reflects the properties of a gas-phase species, it has been known that the correlation between the gas phase and solution is often good for ESI-MS. In comparison to $\mathbf{4}$, the relatively soluble tert-butyl substituted 5 is more appropriate for the latter ${ }^{1} \mathrm{H}$ NMR and UV-vis studies. Thus, among the list of compounds, we chose 2, 3, 5, 6, and 7 for the ESI-MS analysis. The signals of $\mathrm{m} / \mathrm{z}=2 \mathrm{M}+$ $\mathrm{H}$ in the ESI-MS analysis (Table 4) support the formation of dimers of $\mathbf{2}, \mathbf{3}, \mathbf{5}, \mathbf{6}$, and $\mathbf{7}$ in $\mathrm{CHCl}_{3}$. However, the signal intensities in the ESI-MS measurement may be affected by many experimental factors, and the relative intensities do not simply reflect the relative amounts of the species in solution. Therefore, further ${ }^{1} \mathrm{H}$ NMR (in $\mathrm{CDCl}_{3}$ ) and UV-vis spectroscopic experiments (in cyclohexane) were carried out to substantiate the MS results. These experiments should provide quantitative information about the hydrogen-bond directed zipperic self-dimerization.

${ }^{1} \mathbf{H}$ NMR Approaches. ${ }^{1} \mathrm{H}$ and ${ }^{13} \mathrm{C}$ NMR spectra taken in $\mathrm{CDCl}_{3}$ are in agreement with the structural assignments for compounds 2-7. Figure 5 shows the plot of NH's chemical shifts versus concentrations for $\mathbf{2}, \mathbf{3}, \mathbf{5}, \mathbf{6}$, and $\mathbf{7}$ at $30^{\circ} \mathrm{C}$. Note that the $\mathrm{NH}$ peak was chosen to be well separated from the rest of the peaks to gain accuracy. Details for the choice of the specific NH's chemical shifts are provided in the Supporting Information. As shown in Figure 5, the concentrationdependence of the $\delta$ values for the amino protons of $\mathbf{2}, \mathbf{3}, \mathbf{5}, \mathbf{6}$, and 7 suggests hydrogen-bonded dimer formation. ${ }^{17}$ The dimerization constants $K_{\mathrm{d}}, \delta_{\mathrm{i}}$, and $\delta_{\mathrm{f}}$ were obtained from nonlinear

(15) Llamas Saiz, A. L.; Foces-Foces, C. J. Mol. Struct. 1990, 238, 367.

(16) For example, see: Schalley, C. A.; Castellano, R. K.; Brody, M. S.; Rudkevich, D. M.; Siuzdak, G.; Rebek, J., Jr. J. Am. Chem. Soc. 1999 121,4568 .

(17) Connors, K. A. Binding Constants, The Measurement of Molecular Complex Stability; Wiley: New York, 1987; p 202. To simplify the curve fitting process, $\delta_{\mathrm{i}}$ of $\mathbf{2}, \mathbf{3}$, and $\mathbf{5}$, and $\delta_{\mathrm{f}}$ of $\mathbf{7}$ could be directly evaluated from the plot in Figure 5. 

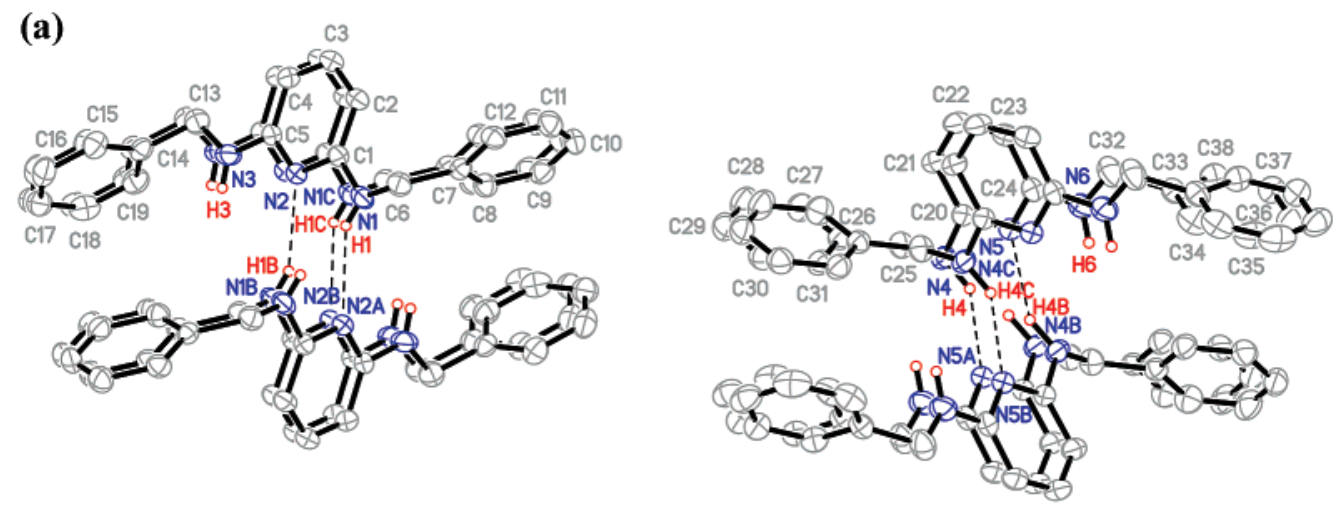

(b)

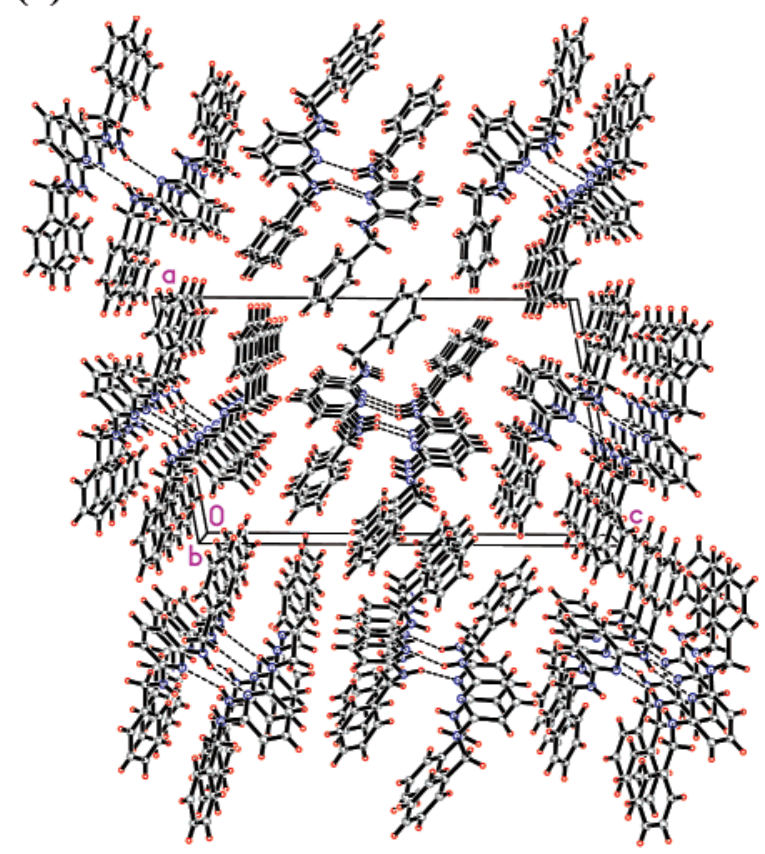

Figure 2. (a) The molecular structure of $\mathbf{2}$ in a polymeric zigzag form. Ellipsoids are drawn at the $30 \%$ probability level. (b) Perspective view of $\mathbf{2 b}$ along the crystallographic $b$ axis.

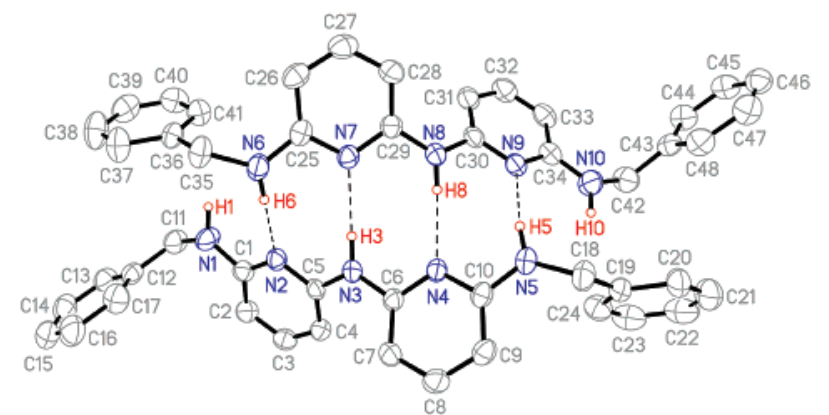

Figure 3. The dimeric structure of $\mathbf{3}$. Ellipsoids are drawn at the $30 \%$ probability level.

least-squares fitting of the data with eq 1 expressed as ${ }^{17}$

$$
\delta=\delta_{\mathrm{i}}+\frac{1+4 K_{\mathrm{d}}[\mathrm{OAP}]-\sqrt{1+8 K_{\mathrm{d}}[\mathrm{OAP}]}}{4 K_{\mathrm{d}}[\mathrm{OAP}]}\left(\delta_{\mathrm{f}}-\delta_{\mathrm{i}}\right)
$$

where $[\mathrm{OAP}]$ is the concentration of oligo-2-aminopyridines used in the measurement. $\delta_{\mathrm{i}}$ and $\delta_{\mathrm{f}}$ are the $\mathrm{NH}$ chemical shifts of oligo-2-aminopyridines in the monomeric and dimeric forms, respectively. The resulting dimerization constants along with

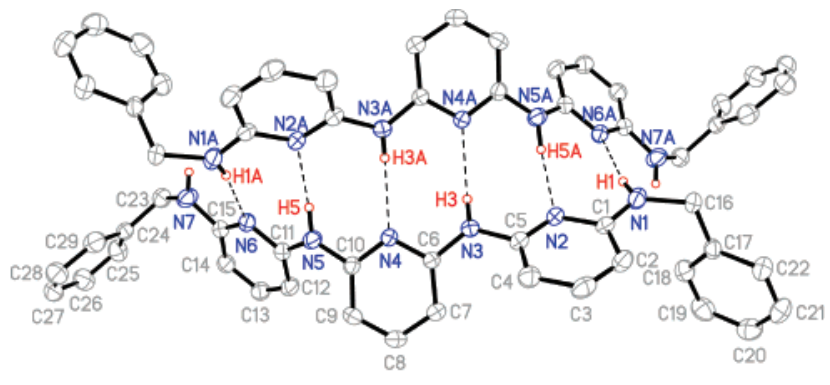

Figure 4. The dimeric structure of $\mathbf{4}$. Ellipsoids are drawn at the $30 \%$ probability level.

values for the dimerization free energy are listed in Table 5. The dimerization constant $K_{\mathrm{d}}$ of $\mathbf{2}$ is too low to be determined accurately. The low $K_{\mathrm{d}}$ value may qualitatively rationalize the unfavorable dimeric formation in the crystal packing. Instead, trimer $\mathbf{2} \mathbf{a}$ and zigzag polymeric chain $\mathbf{2} \mathbf{b}$ are dominant forms (vide supra). In $\mathrm{CDCl}_{3}$, a fair estimation of the $K_{\mathrm{d}}$ value for 2 can be made. The magnitude of $K_{\mathrm{d}}\left(0.034 \mathrm{M}^{-1}\right)$ for 2 in our estimation is reasonably close to the reported value of $K_{\mathrm{d}}(0.2$ $\left.\mathrm{M}^{-1}\right)$ for 2,6- $\left(\mathrm{C}_{5} \mathrm{H}_{11}(\mathrm{CO}) \mathrm{NH}\right)_{2} \mathrm{C}_{5} \mathrm{H}_{3} \mathrm{~N} .{ }^{18}$ In addition, the correlation plot (Figure 6a) shows that the dimerization free energy 
Table 3. Distances between the Donor Nitrogen Atoms and the Acceptor Nitrogen Atoms of the Proximal Hydrogen-Bond Donor-Acceptor Pairs (in Å)

\begin{tabular}{llll}
\hline \multicolumn{2}{c}{ dimer of 3} & \multicolumn{2}{c}{ dimer of 4} \\
\hline N1 $\cdots \mathrm{N} 6$ & 3.798 & $\mathrm{~N} 1 \cdots \mathrm{N} 7$ & 3.788 \\
$\mathrm{~N} 2 \cdots \mathrm{N} 7$ & 3.677 & $\mathrm{~N} 1 \cdots \mathrm{N} 5$ & 3.628 \\
$\mathrm{~N} 3 \cdots \mathrm{N} 6$ & 3.674 & $\mathrm{~N} 2 \cdots \mathrm{N} 6$ & 3.763 \\
$\mathrm{~N} 3 \cdots \mathrm{N} 8$ & 3.747 & $\mathrm{~N} 2 \cdots \mathrm{N} 4$ & 3.665 \\
$\mathrm{~N} 4 \cdots \mathrm{N} 7$ & 3.647 & $\mathrm{~N} 3 \cdots \mathrm{N} 5$ & 3.628 \\
$\mathrm{~N} 4 \cdots \mathrm{N} 9$ & 3.704 & $\mathrm{~N} 3 \cdots \mathrm{N} 3$ & 3.547 \\
$\mathrm{~N} 5 \cdots \mathrm{N} 8$ & 3.669 & $\mathrm{~N} 4 \cdots \mathrm{N} 4$ & 3.804 \\
$\mathrm{~N} 5 \cdots \mathrm{N} 10$ & 3.897 & & \\
mean & 3.72 & mean & 3.69 \\
\hline
\end{tabular}

Table 4. Electrospray lonization Mass Spectral Data of 2, 3, 5, 6, and 7

\begin{tabular}{ccc}
\hline compound $^{a}$ & $\begin{array}{c}m / z=M+H \\
\text { (base peak) }\end{array}$ & $\begin{array}{c}m / z=2 M+H \\
\text { (rel intensity \%) }\end{array}$ \\
\hline $\mathbf{2}$ & 290.2 & $577.3(4)$ \\
$\mathbf{3}$ & 382.3 & $762.7(1)$ \\
$\mathbf{5}$ & 689.6 & $1396.2(19)$ \\
$\mathbf{6}$ & 566.4 & $1130.9(5)$ \\
$\mathbf{7}$ & 882.9 & $1764.0(3)$ \\
\hline
\end{tabular}

${ }^{a}$ The concentrations of the samples were ranged from $1 \times 10^{-3}$ to $3 \times$ $10^{-3} \mathrm{M}$.

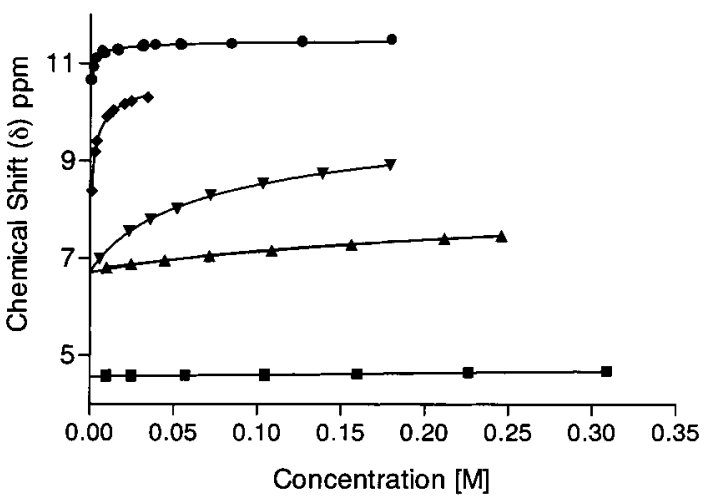

Figure 5. The plot of NH's chemical shifts versus concentrations for 2 $(\square), 3(\boldsymbol{\Delta}), \mathbf{5}(\boldsymbol{\nabla}), \mathbf{6}(\bullet)$, and $\mathbf{7}(\bullet)$ at $30^{\circ} \mathrm{C}$. (-) The best fitted curves for each plot using eq 1 (see text).

Table 5. Dimerization Constants and Thermodynamic Parameters ( $\mathrm{kJ} \mathrm{mol}{ }^{-1}$ ) for 2, 3, 5, 6, and 7 in $\mathrm{CDCl}_{3}$ at $303 \mathrm{~K}$

\begin{tabular}{cccccc}
\hline compound & $\mathrm{n}$ & \multicolumn{1}{c}{$K_{\mathrm{d}}\left[\mathrm{M}^{-1}\right]$} & \multicolumn{1}{c}{$\Delta G_{\text {dim }}^{0}$} & $\Delta H_{\text {dim }}^{0}{ }^{c}$ & \multicolumn{1}{c}{$T \Delta S_{\text {dim }}^{0}{ }^{c}$} \\
\hline $\mathbf{2}$ & 1 & $3.4 \times 10^{-2 a}$ & $8.5 \pm 2.0$ & & \\
$\mathbf{3}$ & 2 & $5.5 \times 10^{-1 b}$ & $1.5 \pm 0.1$ & $-31 \pm 3$ & $-33 \pm 3(32)^{d}$ \\
$\mathbf{5}$ & 3 & $6.8^{b}$ & $-4.8 \pm 0.2$ & $-47 \pm 2$ & $-42 \pm 2(41)^{d}$ \\
$\mathbf{6}$ & 4 & $3.4 \times 10^{2 b}$ & $-14.7 \pm 0.6$ & $-75 \pm 14$ & $-60 \pm 13(59)^{d}$ \\
$\mathbf{7}$ & 5 & $1.0 \times 10^{4 b}$ & $-23.2 \pm 0.4$ & & \\
\hline
\end{tabular}

${ }^{a}$ Standard deviation is $\pm 2.3 \times 10^{-2}$ on the basis of nonlinear leastsquares fitting. ${ }^{b}$ Estimated relative error $<20 \%$. ${ }^{c}$ The values were obtained from a linear plot of $1 / T$ versus $R \ln \left(K_{\mathrm{d}}\right)$, giving the slope equal to $\Delta H_{\mathrm{dim}}^{0}$ and the intercept equal to $\Delta S_{\mathrm{dim}}^{0}{ }^{d}$ Values of $T \Delta S_{\mathrm{dim}}^{0}$ at $298 \mathrm{~K}$.

$\Delta G_{\mathrm{dim}}^{0}$ is linearly correlated to the number of the repeating units with $r=0.99$ in $\mathrm{CDCl}_{3}$. On the basis of Jorgensen's analysis, ${ }^{9 \mathrm{c}, \mathrm{d}}$ a linear correlation equation of $\Delta G_{\mathrm{dim}}^{0}=n(2 \mathrm{P}+$ $4 \mathrm{~S})=n\left(\Delta \Delta G_{\mathrm{dim}}^{0}\right)$ for our zipperic dimers is expected, ${ }^{19}$ where $n$ is the number of repeating units, $\Delta \Delta G_{\mathrm{dim}}^{0}$ denotes the

(18) Beijer, F. H.; Sijbesma, R. P.; Vekemans, J. A. J. M.; Meijer, E. W.; Kooijman, H.; Spek. A. L. J. Org. Chem. 1996, 61, 6371.

(19) The equation was expressed in the convention proposed by Schneider. For references, see: (a) Lüning, U.; Kühl, C. Tetrahedron Lett. 1998, 39, 5735. (b) Sartorius, J.; Schneider, H.-J. Chem.-Eur. J. 1996, 2, 1446.

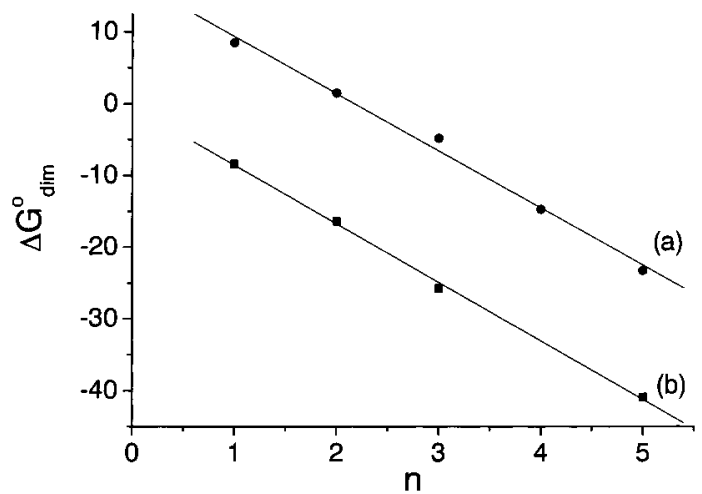

Figure 6. Plot of $\Delta G_{\mathrm{dim}}^{0}\left(\mathrm{~kJ} \mathrm{~mol}^{-1}\right)$ versus $n$, the number of repeating 2-aminopyridine units: (a) in $\mathrm{CDCl}_{3}(303 \mathrm{~K})$, (b) in cyclohexane (298 K).

stabilization free energy arising from the hydrogen-bonding interactions per repeating unit, and $\mathrm{P}$ and $\mathrm{S}$ are the primary and secondary interactions defined by Jorgensen, respectively. However, our correlation plot in Figure 6a shows an empirical correlation of $\Delta G_{\mathrm{dim}}^{0}=n\left(\Delta \Delta G_{\mathrm{dim}}^{0}\right)+\Delta G_{\text {int }}^{0}$ which is slightly different from the predicted equation. Linear least-squares fitting of the data gives $\Delta \Delta G_{\mathrm{dim}}^{0}=-8.0 \mathrm{~kJ} / \mathrm{mol}$ (the slope) and $\Delta G_{\mathrm{int}}^{0}$ $=17.3 \mathrm{~kJ} / \mathrm{mol}$ (the intercept). Although as foreseen by Jorgensen's model where the dimerization free energy is linearly proportional to the number of the repeating units, the presence of a positive intercept, $\Delta G_{\text {int }}^{0},{ }^{20}$ in the correlation plot should not be ignored. Incorporating Schneider's empirical values of -7.9 and $2.9 \mathrm{~kJ} \mathrm{~mol}^{-1}$ for the primary attractive and the secondary repulsive interactions, ${ }^{19 \mathrm{~b}}$ respectively, an increment of $\Delta \Delta G_{\mathrm{dim}}^{0}=-4.2 \mathrm{~kJ} / \mathrm{mol}$ for each of the additional repeating units is anticipated from Jorgensen's equation. In comparison with this prediction, an increment of $\Delta \Delta G_{\mathrm{dim}}^{0}=-8.0 \mathrm{~kJ} / \mathrm{mol}$ from our experiments is larger than the predicted one. These results indicate that the hydrogen-bonding interactions between our helical dimeric pairs are stronger than Schneider's statistical average. These results also suggest that mismatched pairing in the dimer formation is less favored. Mismatched pairing would lead to an increase of the $\Delta G_{\mathrm{dim}}^{0}$, leading to a less stable dimeric form. The presence of a positive intrinsic free energy, $\Delta G_{\text {int }}^{0}$, indicates the existence of intrinsic factors that prevent the monomers from dimerization. These factors are independent of the hydrogen-bonding interactions in dimers, regardless of the units' number. Several possible factors including steric repulsion between terminal substituents, solvation effects, and entropy loss in dimerization may contribute to the nonnegligible $\Delta G_{\text {int. }}^{0}{ }^{21}$

Temperature variation NMR experiments for $\mathbf{3 , 5}$, and $\mathbf{6}$ were carried out to resolve $\Delta G_{\text {dim }}^{0}$ into $\Delta H_{\text {dim }}^{0}$ and $T \Delta S_{\text {dim }}^{0}$ (see Table 5). Linear least-squares fitting of the data gives $\Delta \Delta H_{\operatorname{dim}}^{0}$ and $T\left(\Delta \Delta S_{\mathrm{dim}}^{0}\right)$ to be -22 and $-14 \mathrm{~kJ} / \mathrm{mol}$, respectively, at $303 \mathrm{~K}$. Here the negative $\Delta \Delta H_{\mathrm{dim}}^{0}$ represents the hydrogen-bonding dimerization enthalpy per repeating unit, while the negative $T\left(\Delta \Delta S_{\mathrm{dim}}^{0}\right)$ represents the entropic free-energy loss per repeating unit due to dimerization. Several different factors such as

(20) Our definition of the intrinsic free energy $\Delta G_{\text {int }}^{0}$ in this article is different from the definition of intrinsic binding energy used by Jencks. For reference, see: Jencks, W. P. Proc. Natl. Acad. Sci. U.S.A. 1981, 78, 4046.

(21) (a) Williams, D. H.; Searle, M. S.; Mackay, J. P.; Gerhard, U.; Maplestone, R. A. Proc. Natl. Acad. Sci. U.S.A. 1993, 90, 1172. (b) Williams, D. H. Searle, M. S.; Groves, P.; Mackay, J. P.; Westwell, M. S.; Beauregard, D. A.; Cristofaro, M. F. Pure Appl. Chem. 1994, 66, 1975. 


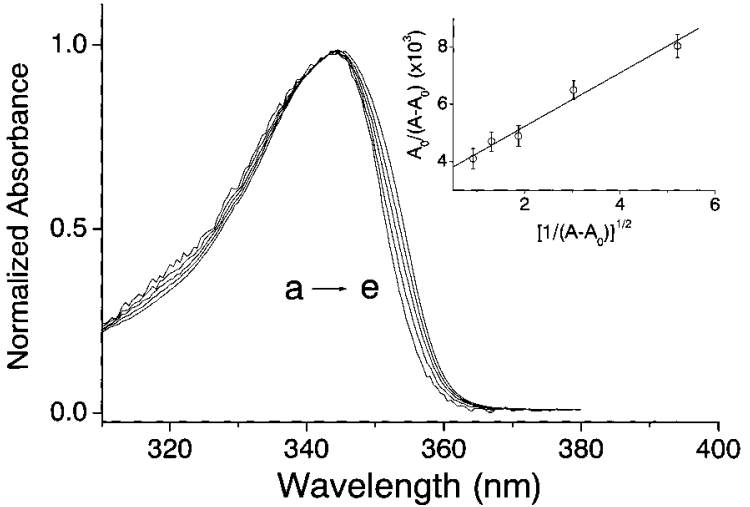

Figure 7. The concentration-dependent absorption spectra of $\mathbf{5}$ in cyclohexane, in which $C_{0}$ was prepared to be (a) $4.2 \times 10^{-6}$, (b) $8.4 \times 10^{-6}$, (c) $1.68 \times 10^{-5}$, (d) $3.36 \times 10^{-5}$, (e) $6.72 \times 10^{-5} \mathrm{M}$. The spectra are normalized at $345 \mathrm{~nm}$. Insert: The plot of $A_{0} /\left(A-A_{0}\right)$ at, e.g., $355 \mathrm{~nm}$ as a function of $\sqrt{1 /\left(A-A_{0}\right)}$.

internal rotational restrictions of monomers due to dimer formation or desolvation of the solvent molecules may have contributed to $T\left(\Delta \Delta S_{\mathrm{dim}}^{0}\right)$. Even though in principle the slope and intercept of the plots to $n=0$ would give $\Delta H_{\text {int }}^{0}$ and $T \Delta S_{\text {int }}^{0}$, respectively, uncertainty due to curve fitting would limit the reliability of these parameters, leading to a less conclusive prediction.

UV - Vis Absorption Measurements. It is of key importance to mimic the intrinsic hydrogen-bonding effect in the nonpolar solvent that provides an environment free from the solvent perturbation such as polar(solute)-polar(solvent) and/or solvent hydrogen-bond interactions. Alternatively, the concentrationdependent absorption spectroscopy offers a reliable method because the dual hydrogen-bond formation of the 2-aminopyridine unit might alter the $S_{0} \rightarrow S_{1}\left(\pi, \pi^{*}\right)$ chromophore due to the associated charge-transfer effect. ${ }^{22}$ Here, compound 5 was used as a prototype to demonstrate such feasibility. When the concentration was prepared to be as low as $1.2 \times 10^{-6} \mathrm{M}, \mathbf{5}$ exhibits the lowest singlet $\pi \rightarrow \pi^{*}$ absorption band maximum at $345 \mathrm{~nm}\left(\epsilon_{345} \approx 4.3 \times 10^{4} \mathrm{M}^{-1} \mathrm{~cm}^{-1}\right)$. Upon increasing the concentration, changes in the spectral features were observed in which the spectra after normalization reveal significant red shift (see Figure $7 \mathrm{a}-\mathrm{e}$ ). The results unambiguously conclude the formation of dimer and/or higher-order aggregates through the hydrogen-bonding effect. On the basis of the dimeric structure resolved from X-ray, we first assume a dominant dimeric formation, which possesses a spiral, cyclic type of six hydrogen-bond configurations. The dimerization constant $K_{\mathrm{d}}$ can thus be extracted from eq 2

$$
\frac{A_{0}}{A-A_{0}}=\sqrt{\frac{l \epsilon_{\mathrm{M}}^{2}}{\epsilon_{\mathrm{D}}-2 \epsilon_{\mathrm{M}}}} \cdot \sqrt{\frac{1}{K_{\mathrm{d}}}} \cdot \sqrt{\frac{1}{A-A_{0}}}+\frac{2 \epsilon_{\mathrm{M}}}{\epsilon_{\mathrm{D}}-2 \epsilon_{\mathrm{M}}}
$$

where $A$ and $l$ denote the initially prepared absorbance at a selected wavelength and cell path length, respectively. $\epsilon_{M}$ and $\epsilon_{\mathrm{D}}$ are the molar extinction coefficients of monomer and dimer at the selected wavelength. $A_{0}$ is the absorbance of the monomer assuming that no dimer is formed. Experimentally, $\epsilon_{\mathrm{M}}$ can be resolved by performing the absorption titration study at a sufficiently low concentration where the monomer exists

(22) Chou, P. T.; Wu, G. R.; Wei, C. Y.; Cheng, C. C.; Chang, C. P.; Hung, F. T. J. Phys. Chem. B 2000, 104, 7818 .
Table 6. Values of $\Delta G_{\text {dim }}^{0}, \Delta H_{\text {dim }}^{0}$, and $T \Delta S_{\text {dim }}^{0}$ upon Dimerization as a Function of the Repeating Unit of 2-Aminopyridine at $298 \mathrm{~K}$ (in $\mathrm{kJ} \mathrm{mol}^{-1}$ )

\begin{tabular}{ccccc}
\hline compound & $n$ & $\Delta G_{\text {dim }}^{0}$ & $\Delta H_{\text {dim }}^{0}$ & \multicolumn{1}{c}{$T \Delta S_{\text {dim }}^{0}$} \\
\hline $\mathbf{2}$ & 1 & $-(7.2 \pm 0.7)$ & $-(52 \pm 3)$ & $-(45 \pm 3)$ \\
$\mathbf{3}$ & 2 & $-(15.0 \pm 1.5)$ & $-(68 \pm 5)$ & $-(53 \pm 5)$ \\
$\mathbf{5}$ & 3 & $-(23.3 \pm 2.1)$ & $-(86 \pm 5)$ & $-(63 \pm 7)$ \\
$\mathbf{7}$ & 5 & $-(39.6 \pm 3.2)$ & $-(124 \pm 8)$ & $-(84 \pm 10)$ \\
\hline
\end{tabular}

prevalently. A detailed derivation of eq 2 is described in the Appendix. The plot of $A_{0} /\left(A-A_{0}\right)$ at, for example, $355 \mathrm{~nm}$ as a function of $1 /\left(\sqrt{A-A_{0}}\right)$ shown in the insert of Figure 7 reveals sufficiently linear behavior, supporting the assumption of dimeric formation in $\mathbf{5}$. The best linear least-squares fit to the insert of Figure 7 gives a $K_{\mathrm{d}}$ value of $(1.2 \pm 0.5) \times 10^{4}$ $\mathrm{M}^{-1}\left(\epsilon_{\mathrm{D}}^{355} \approx 8.02 \times 10^{4} \mathrm{M}^{-1} \mathrm{~cm}^{-1}\right)$. The hydrogen-bonded association in $\mathbf{5}$ can be further supported by the concentrationdependent fluorescence spectra of which the fluorescence maximum is gradually red shifted from $\sim 368 \mathrm{~nm}\left(4.2 \times 10^{-6}\right.$ M) to $\sim 378 \mathrm{~nm}\left(8.4 \times 10^{-5} \mathrm{M}\right.$, not shown here $){ }^{23}$ Dual fluorescence lifetime of 3.1 and 1.8 ns originating from monomer and dimer, respectively, was resolved. ${ }^{23}$ Temperaturedependent absorption titration spectra were also performed to resolve $\Delta G_{\mathrm{dim}}^{0}$ into $\Delta H_{\mathrm{dim}}^{0}$ and $T \Delta S_{\mathrm{dim}}^{0}$. The logarithm plot of dimerization constants as a function of the reciprocal of the temperature renders linear behavior, and $\Delta H_{\text {dim }}^{0}$ was deduced to be $\sim-86 \mathrm{~kJ} / \mathrm{mol}$ for $\mathbf{5}$. Similar spectroscopic methods were applied to $\mathbf{2 , 3}$, and $\mathbf{7}$ in cyclohexane where prevalent hydrogenbonded dimerization upon association was also observed. Accordingly, the best fit of data based on eq 1 gives rise to $K_{\mathrm{d}}$ values of $(1.8 \pm 0.5) \times 10^{1},(4.2 \pm 1.5) \times 10^{2}$, and $(8.7 \pm 1.5)$ $\times 10^{6} \mathrm{M}^{-1}$ for $\mathbf{2}, \mathbf{3}$, and $7,{ }^{24}$ respectively. The sparse solubility of $\mathbf{6}$ in cyclohexane due to the lack of tert-butyl substituents makes the extraction of thermodynamic data upon dimerization infeasible. Figure $6 \mathrm{~b}$ reveals a plot of the dimerization free energy $\Delta G_{\mathrm{dim}}^{0}$ as a function of the number of the repeating 2 -aminopyridine units $n$. Again, as foreseen by the Jorgensen model, the dimerization free energy is linearly proportional to the number of the repeating hydrogen-bond units. A linear leastsquares fit of the data based on an empirical correlation of $\Delta G_{\mathrm{dim}}^{0}=n\left(\Delta \Delta G_{\mathrm{dim}}^{0}\right)+\Delta G_{\mathrm{int}}^{0}$ results in $\Delta \Delta G_{\mathrm{dim}}^{0}$ and $\Delta G_{\mathrm{int}}^{0}$ of -8.3 and $1.5 \mathrm{~kJ} / \mathrm{mol}$, respectively. The fact that the value of $\Delta G_{\text {int }}^{0}$ in cyclohexane is much smaller than that in $\mathrm{CDCl}_{3}$, indicating the applicability of the Jorgensen model in a nonpolar solvent, is worth mentioning here. Table 6 lists the values of $\Delta G_{\mathrm{dim}}^{0}, \Delta H_{\mathrm{dim}}^{0}$, and $T \Delta S_{\mathrm{dim}}^{0}(298 \mathrm{~K})$ upon dimerization as a function of the repeating unit of 2-aminopyridine in cyclohexane. The correlation plots of the data obtained from temperature variation experiments versus the number of the repeating units result in $\Delta \Delta H_{\mathrm{dim}}^{0}=-18 \mathrm{~kJ} / \mathrm{mol}$ and $T\left(\Delta \Delta S_{\mathrm{dim}}^{0}\right)=-9.8 \mathrm{~kJ} / \mathrm{mol}$ at $298 \mathrm{~K}$ (not shown here).

The enthalpy/entropy compensation effect ${ }^{21,25}$ is observed in our system. Figure 8 shows a plot of $\Delta H_{\mathrm{dim}}^{0}$ versus $T \Delta S_{\mathrm{dim}}^{0}$ at $T$ $=298 \mathrm{~K}$ that integrates the data for $\mathbf{2 , 3 , 5 , 6}$, and $\mathbf{7}$ in both solvents. The plot is a sufficiently straight line with a slope of

(23) To avoid the inner filter effect, a configuration of front-face excitation was applied throughout the fluorescence study.

(24) Because of the large $K_{\mathrm{d}}$ value, a very low concentration of 7 is required to perform the concentration-dependent study. Accordingly, $4 \mathrm{~cm}$ and $10 \mathrm{~cm}$ path length cells were incorporated in the absorption titration study.

(25) Williams, D. H.; O'Brien, D. P.; Bardsley, B. J. Am. Chem. Soc. 2001, 123,737 . 


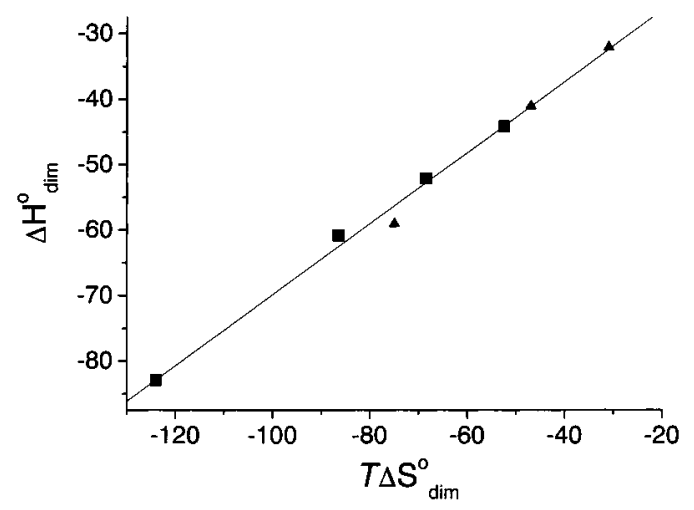

Figure 8. The correlation plot of $\Delta H_{\mathrm{dim}}^{0}\left(\mathrm{~kJ} \mathrm{~mol}^{-1}\right)$ versus $T \Delta S_{\mathrm{dim}}^{0}(\mathrm{~kJ}$ $\mathrm{mol}^{-1}$ ) at $298 \mathrm{~K}$ : (ム) data in $\mathrm{CDCl}_{3}$; (苂) data in cyclohexane.

0.54, suggesting that around $54 \%$ of the enthalpy gain from dimerization interactions would be sacrificed to compensate for the entropic free-energy loss. On the basis of the plot, one could perceive that large decreases in enthalpies are linearly correlated to the decreases in entropies upon dimerization. Data obtained either in cyclohexane or in $\mathrm{CDCl}_{3}$ follow the same correlation. These results could be rationalized by the hydrogen-bond effect. Although the hydrogen-bonding formation between the monomers would gain significant amounts of the enthalpic stabilization energy, the increased hydrogen-bond interactions would reduce internal motions of the monomers, resulting in a loss of entropy. These results also imply the formation of a relatively tighter dimeric pair in cyclohexane than that in $\mathrm{CDCl}_{3}$.

The intrinsic $\mathrm{CDCl}_{3}$ - solute interaction may be qualitatively rationalized through an ab initio approach. To simplify the calculations, the terminal $N$-benzylic groups were replaced with $\mathrm{N}$-methyl groups for 2-4, forming 2-Me, 3-Me, and 4-Me. The initial geometry of monomers and dimers was adopted from $\mathrm{X}$-ray structures for 3 and 4 . As $\mathrm{C}-\mathrm{H} \cdots \mathrm{N}$ interactions have been documented in the literature, ${ }^{26-28}$ we first attempted to explore whether chloroform desolvation plays a role in the process of dimerization. Although the $\mathrm{C}-\mathrm{H}$ bond of chloroform has been shown to be a potential proton donor, ${ }^{29-32}$ the proton acceptor ability of a chlorine atom is less obvious. Meanwhile, the interactions between chloroform molecules are quite weak. The complexation energy of the best geometrically optimized chloroform dimer that was located is $-1.55 \mathrm{~kJ} / \mathrm{mol}$ and can thus be neglected. Accordingly, as a crude approximation, it was assumed that prior to the dimerization formation at least one $\mathrm{C}-\mathrm{H} \cdots \mathrm{N}$ interaction has to be broken for each pyridine ring. In other words, one and two chloroform molecules have to be decomplexed from monomeric 2-Me and 3-Me, respectively, in advance of dimerization. Note that more solvent molecules in the solvation shell have to be relocated in real solution upon proceeding to dimerization. Nevertheless, our

(26) (a) Desiraju, G. R. Angew. Chem., Int. Ed. Engl. 1995, 34, 2311-2327 and references therein. (b) Marjo, C. E.; Bishop, R.; Craig, D. C.; Scudder, M. L. Eur. J. Org. Chem. 2001, 863.

(27) Hilfiker, M. A.; Mysak, E. R.; Samet, C.; Maynard, A. J. Phys. Chem. A 2001, 105, 3087.

(28) Gu, Y.; Kar, T.; Scheiner, S. J. Mol. Struct. 2000, 552, 17-31.

(29) (a) Desiraju, G. R. J. Chem. Soc., Chem. Commun. 1989, 179. (b) Desiraju, G. R. Acc. Chem. Res. 1991, 24, 290-296.

(30) Jemmis, E. D.; Giju, K. T.; Sundararajan, K.; Sankaran, K.; Vidya, V.; Viswanathan, K. S.; Leszczynski, J. J. Mol. Struct. 1999, 510, 59.

(31) Our calculation at the MP2/6-31G** level estimated the BSSE corrected binding energy of $\mathrm{CHCl}_{3} \cdots \mathrm{NH}_{3}$ complex to be $-23.26 \mathrm{~kJ} / \mathrm{mol}$.

(32) Pawelka, Z.; Koll, A.; Zeegers-Huyskens, Th. J. Mol. Struct. 2001, 597, 57. preliminary approach should provide certain clues about the relative importance of solute-solute and solute-solvent interactions.

Several interesting observations were made from the calculation results. First, all calculated $(\mathrm{C}-) \mathrm{H} \cdots \mathrm{N}$ distances are within the sum of van der Waals radii of $\mathrm{H}$ and $\mathrm{N}(2.6 \AA)$, while all $(\mathrm{N}-) \mathrm{H} \cdots \mathrm{Cl}$ and $(\mathrm{C}-) \mathrm{H} \cdots \mathrm{Cl}$ distances are larger than the sum of van der Waals radii of $\mathrm{H}$ and $\mathrm{Cl}(2.9 \AA)$. In almost all cases, the $\mathrm{C}-\mathrm{H} \cdots \mathrm{N}$ angle is more linear than the $\mathrm{N}-\mathrm{H} \cdots \mathrm{Cl}$ and $\mathrm{C}-\mathrm{H} \cdots \mathrm{Cl}$ angles. The results implied that $\mathrm{C}-\mathrm{H} \cdots \mathrm{N}$ interaction is of primary importance, while the $\mathrm{N}-\mathrm{H} \cdots \mathrm{Cl}$ and $\mathrm{C}-\mathrm{H} \cdots \mathrm{Cl}$ interactions are minor parts. Second, at the B3LYP/6-31+G**// $\mathrm{HF} / 6-31 \mathrm{G}^{*}$ level, the gas-phase complexation energies of 2-Me $\cdot \mathrm{CHCl}_{3}(-17.45 \mathrm{~kJ} / \mathrm{mol})$ and $\mathbf{3}-\mathbf{M e} \cdot 2 \mathrm{CHCl}_{3}(-23.47 \mathrm{~kJ} /$ $\mathrm{mol})$ are a few $\mathrm{kJ} / \mathrm{mol}$ smaller than those of $(\mathbf{2}-\mathbf{M e})_{2}(-28.87$ $\mathrm{kJ} / \mathrm{mol})$ and $(3-\mathrm{Me})_{2}(-42.63 \mathrm{~kJ} / \mathrm{mol})$. Thus, the magnitude of the solute-solvent interaction in chloroform is far from negligible. In comparison, much less solvation outcomes can be expected with less polar or acidic solvents such as cyclohexane, consistent with the experimental results. Finally, the dimerization energies of 2-Me, 3-Me, and 4-Me were calculated to be $-28.87,-42.63$, and $-61.63 \mathrm{~kJ} / \mathrm{mol}$, respectively, at the B3LYP/6-31+G**//HF/6-31G* level. The plot of $\Delta E_{\text {dimer }}$ (see Experimental Section) versus the number of the repeating 2 -aminopyridine groups shows linear behavior $\left(R^{2} \approx 0.991\right.$, not shown here). However, the increase of complexation energy is not a simple multiple of the number of hydrogen bonds. For example, the complexation energy of $(\mathbf{3}-\mathbf{M e})_{2}$ is less than twice that of $(\mathbf{2}-\mathbf{M e})_{2}$, possibly due to secondary interactions. In (2-Me $)_{2}$, the unbound $\mathrm{N}-\mathrm{H}$ group twists out of the molecular plane to avoid secondary interactions. However, for the formation of two additional hydrogen bonds in $(3-\mathbf{M e})_{2}$, the middle $\mathrm{N}-\mathrm{H}$ group, which corresponds to the unbound $\mathrm{N}-\mathrm{H}$ bond in (2-Me $)_{2}$, has to be brought back to the vicinity of a neighboring $\mathrm{N}-\mathrm{H}$ group of the binding partner (see Figures 2 and 3 for reference). For 3-Me $2 \mathrm{CHCl}_{3}$, the unfavorable dipole-dipole interaction between the two chloroform molecules cancels out some of the favorable solute-solvent interactions. Therefore, decomplexation of the second chloroform molecule becomes relatively easy. A similar trend was applied to oligo-2aminopyridines with higher repeating $n(>3)$ units. The results qualitatively rationalize the difference in $\Delta G_{\text {int }}$, while $\Delta \Delta G_{\text {dim }}$ is similar between $\mathrm{CDCl}_{3}$ and cyclohexane. Further detailed studies focusing on the molecular dynamics simulation are in progress.

\section{Conclusion}

In summary, we have demonstrated a systematic approach to evaluate the strength of hydrogen-bonding interactions. Jorgensen's model can be successfully applied to our systems in cyclohexane. However, the intrinsic free energy $\Delta G_{\text {int }}^{0}$ has to be considered if the dimerization studies are carried out in $\mathrm{CDCl}_{3}$ in which $\Delta G_{\text {int }}^{0}$ is an important parameter that works against the monomers from dimerization. Our results show the enthalpy/ entropy compensation relationship as a competition between bonding and dynamics. Although increasing the number of hydrogen-bonding interactions would definitely enhance the hydrogen-bonding stabilization enthalpy, this stabilization enthalpy per unit would be partially sacrificed to compensate for the entropic free-energy loss due to dimerization in our cases. 
These results clearly support the importance of "the concept of preorganization" $33-35$ in the design of hydrogen-bonding guesthost molecules.

\section{Experimental Section}

4.1. Materials. Tris(dibenzylideneacetone)dipalladium $(0)\left(\mathrm{Pd}_{2}(\mathrm{dba})_{3}\right.$, 2,2'-bis(diphenylphosphino)-1,1'-binaphthyl (BINAP), potassium-tertbutoxide $(\mathrm{KO}-t \mathrm{Bu})$, and 18 -crown-6 were obtained commercially (Aldrich, Janssan, Tokyo Kasei) and used as received. Benzene was refluxed over calcium hydride for $8 \mathrm{~h}$ before use.

4.2. General Procedures for Synthesizing 2-7. A mixture of the corresponding bromide and amine, $\mathrm{Pd}_{2}(\mathrm{dba})_{3}$, BINAP, KO- $t \mathrm{Bu}$, and 18 -crown-6 in dry benzene $(10 \mathrm{~mL})$ was refluxed at $80^{\circ} \mathrm{C}$ under argon with constant stirring. After reacting for a specified time period, the reaction mixture was cooled and quenched with $\mathrm{NH}_{4} \mathrm{Cl}$ solution $(2 \mathrm{~mL})$. The product was extracted twice with $\mathrm{CH}_{2} \mathrm{Cl}_{2}$. The extracts were combined and washed with $\mathrm{H}_{2} \mathrm{O}(2 \mathrm{~mL})$, dried over anhydrous $\mathrm{MgSO}_{4}$, and concentrated under reduced pressure to provide a crude oil, which was further purified by column chromatography over silica gel. In most cases, a mixture of ethyl acetate and hexane is a suitable eluent for column chromatography. Although the products isolated by this approach are reasonably good in their NMR spectra and elemental analysis, the products usually contained trace amounts of brown impurity that would significantly affect the experiments in the UVvis analysis. Therefore, compounds $\mathbf{2 , 3 , 5}$, and $\mathbf{7}$ were further purified through column chromatography (diethyl ether) to remove the brown impurity before analysis.

Bis[6-(benzylamino)pyrid-2-yl]amine (3). The reaction of $(\mathrm{N}$ benzyl)pyridine-2,6-diamine (8) $(0.199 \mathrm{~g}, 1 \mathrm{mmol})$ and 2-( $N$-benzylamino)-6-bromopyridine (10) $(0.262 \mathrm{~g}, 1 \mathrm{mmol})$ in the presence of $\mathrm{Pd}_{2-}$ $(\mathrm{dba})_{3}(0.010 \mathrm{~g}, 1 \mathrm{~mol} \%)$, BINAP $(0.012 \mathrm{~g}, 2 \mathrm{~mol} \%)$, and KO- $t \mathrm{Bu}$ $(0.448 \mathrm{~g}, 4 \mathrm{mmol})$ in benzene $(10 \mathrm{~mL})$ for $8 \mathrm{~h}$ gave a crude product 3 . Purification by column chromatography over silica gel, using hexane/ EtOAc (4:1) as eluent, gave the pure bis[6-(benzylamino)pyrid-2-yl]amine (3) (0.304 g, 79\% yield) as colorless crystals. $R_{f} 0.50$ (hexane/ EtOAc, 7:3). mp $131{ }^{\circ} \mathrm{C}$. IR (KBr): $3421,3265,1610 \mathrm{~cm}^{-1} .{ }^{1} \mathrm{H}$ NMR $\left(200 \mathrm{MHz}, \mathrm{DMSO}-d_{6}\right): \delta 8.47(\mathrm{~s}, 1 \mathrm{H}, \mathrm{NH}), 7.36-7.09(\mathrm{~m}, 12 \mathrm{H}), 6.77$ $(\mathrm{d}, J=8.0 \mathrm{~Hz}, 2 \mathrm{H}), 6.73(\mathrm{t}, J=6 \mathrm{~Hz}, 2 \mathrm{H}, \mathrm{NH}), 5.93(\mathrm{~d}, J=8.0 \mathrm{~Hz}$, $2 \mathrm{H}), 4.46(\mathrm{~d}, J=6 \mathrm{~Hz}, 4 \mathrm{H}) .{ }^{13} \mathrm{C}$ NMR $\left(100 \mathrm{MHz}\right.$, DMSO- $\left.d_{6}\right): \delta$ 158.89, 139.63, 139.43, 139.37, 128.19, 127.27, 126.65, 114.05, 106.53, 44.18. EI-MS: 381 [M $\mathrm{M}^{+}$]. Anal. Calcd for $\mathrm{C}_{24} \mathrm{H}_{23} \mathrm{~N}_{5}$ : C, 75.55; H, 6.08; N, 18.37. Found: C, 75.19; H, 6.15; N, 18.86 .

$N^{2}, N^{6}$-Bis[6'-(benzylamino)pyrid-2'-yl]pyridine-2,6-diamine (4). The reaction of ( $N$-benzyl)pyridine-2,6-diamine $(\mathbf{8})(0.398 \mathrm{~g}, 2 \mathrm{mmol})$ and 2,6-dibromopyridine $(0.237 \mathrm{~g}, 1 \mathrm{mmol})$ in the presence of $\mathrm{Pd}_{2-}$ $(\mathrm{dba})_{3}(0.021 \mathrm{~g}, 2 \mathrm{~mol} \%)$, BINAP $(0.025 \mathrm{~g}, 4 \mathrm{~mol} \%)$, KO- $t \mathrm{Bu}(0.56$ $\mathrm{g}, 5 \mathrm{mmol})$, and 18 -crown-6 $(1.3 \mathrm{gm}, 5 \mathrm{mmol})$ in benzene $(20 \mathrm{~mL})$ for $16 \mathrm{~h}$ gave a crude 4 . Purification by column chromatography over silica gel, using hexane/EtOAc (7:3) as eluent, gave $4(0.34 \mathrm{~g}, 72 \%$ yield $)$ as yellow crystals. $R_{f} 0.45$ (hexane/EtOAc, 7:3). mp $188^{\circ} \mathrm{C}$. IR $(\mathrm{KBr})$ : 3437, 3232, $1604 \mathrm{~cm}^{-1} .{ }^{1} \mathrm{H}$ NMR (300 MHz, DMSO- $\left.d_{6}\right): \delta 8.67$ (s, 2H, NH), 7.37-7.20 (m, 13H), $7.12(\mathrm{~d}, J=7.8 \mathrm{~Hz}, 2 \mathrm{H}), 6.85-6.81$ $(\mathrm{m}, 4 \mathrm{H}), 6.00(\mathrm{~d}, J=7.8 \mathrm{~Hz}, 2 \mathrm{H}), 4.49(\mathrm{~d}, J=6 \mathrm{~Hz}, 4 \mathrm{H}) .{ }^{13} \mathrm{C} \mathrm{NMR}$ $\left(100 \mathrm{MHz}, \mathrm{DMSO}-d_{6}\right): \delta 157.45,153.14,152.68,140.97,138.14$, 138.09, 128.14, 127.07, 126.40, 102.64, 98.90, 98.72, 44.32. FABMS: $m / z, 473\left[\mathrm{M}^{+}\right]$. Anal. Calcd for $\mathrm{C}_{29} \mathrm{H}_{27} \mathrm{~N}_{7}: \mathrm{C}, 73.53 ; \mathrm{H}, 5.74 ; \mathrm{N}$, 20.71. Found: C, 73.20; H, 5.73; N, 20.73.

$N^{2}, N^{6}$-Bis [6' -(3", $5^{\prime \prime}$-di-tert-butylbenzylamino)pyrid-2' -yl]pyridine2,6-diamine (5). The reaction of $N$-( $3^{\prime}, 5^{\prime}$-di-tert-butylbenzyl)pyridine-

(33) Cram, D. J. Angew. Chem., Int. Ed. Engl. 1986, 25, 1039.

(34) Martell, A. E.; Hancock, R. D.; Motekaitis, R. J. Coord. Chem. Rev. 1994 $133,39$.

(35) For recent examples based on the concept of preorganization, see: (a) Bell, T. W.; Khasanov, A. B.; Drew, M. G. B.; Filikov, A.; James, T. L. Angew. Chem., Int. Ed. 1999, 38, 2543. (b) Bell, T. W.; Hou, Z.; Zimmerman, S. C.; Thiessen, P. A. Angew. Chem., Int. Ed. Engl. 1995, 34, 2163. 2,6-amine (9) (0.622 g, 2 mmol) and 2,6-dibromopyridine (0.237 g, 1 $\mathrm{mmol})$ in the presence of $\operatorname{Pd}_{2}(\mathrm{dba})_{3}(0.021 \mathrm{~g}, 2 \mathrm{~mol} \%)$, BINAP $(0.025$ $\mathrm{g}, 4 \mathrm{~mol} \%)$, and $\mathrm{KO}-\mathrm{Bu}(0.448 \mathrm{~g}, 4 \mathrm{mmol})$ in benzene $(20 \mathrm{~mL})$ for $8 \mathrm{~h}$ gave a crude $\mathbf{5}$. Purification by column chromatography over silica gel, using hexane/EtOAc (7:3) as eluent, gave pure $5(0.468 \mathrm{~g}, 67 \%$ yield) as yellow solid. $R_{f} 0.50$ (hexane/EtOAc, $\left.4: 1\right)$. mp $120{ }^{\circ} \mathrm{C}$. IR (KBr): 3409, 3229, $1614 \mathrm{~cm}^{-1} .{ }^{1} \mathrm{H}$ NMR $\left(400 \mathrm{MHz}, \mathrm{CDCl}_{3}\right): \delta 8.75$ (s, 2H, NH), 7.44-7.21 (m, 9H), $7.11(\mathrm{~d}, J=7.6 \mathrm{~Hz}, 2 \mathrm{H}), 6.59(\mathrm{~d}, J$ $=8.0 \mathrm{~Hz}, 2 \mathrm{H}), 5.96(\mathrm{~d}, J=8.0 \mathrm{~Hz}, 2 \mathrm{H}), 5.25(\mathrm{bs}, 2 \mathrm{H}, \mathrm{NH}), 4.40(\mathrm{~d}$, $J=5.6 \mathrm{~Hz}, 4 \mathrm{H}), 1.31(\mathrm{~s}, 36 \mathrm{H}) .{ }^{13} \mathrm{C} \mathrm{NMR}\left(100 \mathrm{MHz}, \mathrm{CDCl}_{3}\right): \delta 158.53$, $153.67,153.52,150.95,139.16,139.05,138.18,121.54,121.08,103.24$, 99.73, 97.72, 47.27, 34.77, 31.42. FAB-MS: $697\left[\mathrm{M}^{+}\right]$. Anal. Calcd for $\mathrm{C}_{45} \mathrm{H}_{59} \mathrm{~N}_{7}$ : C, $77.42 ; \mathrm{H}, 8.53 ; \mathrm{N}, 14.05$. Found: $\mathrm{C}, 77.46 ; \mathrm{H}, 8.60$; $\mathrm{N}, 13.91$

$\operatorname{Bis}\left\{6-\left[6^{\prime}\right.\right.$-(benzylamino)pyrid-2'-yl)amino]pyrid-2-yl $\}$ amine (6). The reaction of $N^{6}$-(6'-bromopyrid-2-yl)- $N^{2}-\left(6^{\prime \prime}\right.$-(benzylamino)pyrid2-yl)pyridine-2,6-diamine (13) (0.446 g, $1 \mathrm{mmol})$ and ( $N$-benzyl)pyridine-2,6-diamine $(\mathbf{8})(0.199 \mathrm{~g}, 1 \mathrm{mmol})$ in the presence of $\mathrm{Pd}_{2}(\mathrm{dba})_{3}$ (0.021 g, 2 mol \%), BINAP (0.025 g, 4 mol \%), KO- $t$ Bu (0.448 g, 4 mmol), and 18-crown-6 (0.65 g, $2.5 \mathrm{mmol})$ in benzene $(10 \mathrm{~mL})$ for 8 h gave a crude 6. Purification by column chromatography over silica gel $\left(\mathrm{CH}_{2} \mathrm{Cl}_{2}\right.$ /acetone, $\left.24: 1\right)$ gave pure $6(0.362 \mathrm{~g}, 64 \%$ yield $)$ as a brown solid. $R_{f} 0.38$ (hexane:EtOAc, $3: 2$ ). $\mathrm{mp} 181^{\circ} \mathrm{C}$. IR (KBr): 3421,3195 , $1602,1580 \mathrm{~cm}^{-1} .{ }^{1} \mathrm{H}$ NMR $\left(400 \mathrm{MHz}, \mathrm{CDCl}_{3}\right): \delta 10.17(\mathrm{~s}, 1 \mathrm{H}, \mathrm{NH})$, 9.73 (s, 2H, NH), 7.41 (t, $J=8 \mathrm{~Hz}, 2 \mathrm{H}), 7.29-7.18(\mathrm{~m}, 12 \mathrm{H}), 6.99$ $(\mathrm{d}, J=8 \mathrm{~Hz}, 2 \mathrm{H}), 6.82(\mathrm{~d}, J=8 \mathrm{~Hz}, 2 \mathrm{H}), 6.53(\mathrm{~d}, J=8 \mathrm{~Hz}, 2 \mathrm{H})$, $5.86(\mathrm{~d}, J=8 \mathrm{~Hz}, 2 \mathrm{H}), 5.62(\mathrm{bs}, 2 \mathrm{H}, \mathrm{NH}), 4.35(\mathrm{~d}, J=5.6 \mathrm{~Hz}, 4 \mathrm{H})$. ${ }^{13} \mathrm{C}$ NMR (100 MHz, DMSO- $\left.d_{6}\right): \delta 157.45,153.12,152.68,152.58$, 140.93, 138.37, 138.11, 128.14, 127.06, 126.40, 102.92, 102.86, 98.92, 98.72, 44.35. FAB-MS: $565\left[\mathrm{M}^{+}\right]$. HRMS calcd for $\mathrm{C}_{34} \mathrm{H}_{31} \mathrm{~N}_{9}$, 565.2702; found, 565.2698.

$N^{2}, N^{6}-\left\{6^{\prime}-\left[6^{\prime \prime}-\left(3^{\prime \prime \prime}, 5^{\prime \prime \prime}-\right.\right.\right.$ Di-tert-benzylamino $)$ pyrid-2"'-yl)amino $]$ pyrid-2'-yl $\}$ pyridine-2,6-diamine (7). The reaction of $N$-( $3^{\prime}, 5^{\prime}$-di-tertbutylbenzyl)pyridine-2,6-amine (9) $(0.622 \mathrm{~g}, 2 \mathrm{mmol})$ and $N^{2}, N^{6}$-bis $\left(6^{\prime}-\right.$ bromopyrid-2'-yl)pyridine-2,6-diamine (12) $(0.419 \mathrm{~g}, 1 \mathrm{mmol})$ in the presence of $\operatorname{Pd}_{2}(\mathrm{dba})_{3}(0.032 \mathrm{~g}, 3 \mathrm{~mol} \%)$, BINAP $(0.038 \mathrm{~g}, 6 \mathrm{~mol} \%)$, $\mathrm{KO}-\mathrm{tBu}(0.56 \mathrm{~g}, 5 \mathrm{mmol})$, and 18-crown-6 $(0.528 \mathrm{~g}, 2 \mathrm{mmol})$ in benzene $(10 \mathrm{~mL})$ for $8 \mathrm{~h}$ gave a crude 7 . Purification by column chromatography over silica gel (hexane/EtOAc, 3:2) gave pure $7(581 \mathrm{mg}, 66 \%)$ as a yellow solid. $R_{f} 0.58$ (hexane:EtOAc, 7:3). mp $139^{\circ} \mathrm{C}$. IR (KBr): 3418 , $3228,3201,1613 \mathrm{~cm}^{-1} .{ }^{1} \mathrm{H}$ NMR $\left(400 \mathrm{MHz}, \mathrm{CDCl}_{3}\right): \delta 11.39(\mathrm{~s}, 2 \mathrm{H}$, $\mathrm{NH}), 10.70$ (bs, 2H, NH), 7.44-7.40 (m, 3H), 7.20-7.36 (m, 6H), 7.19 (s, 4H), 7.07 (bs, 2H), $6.76(\mathrm{~m}, 4 \mathrm{H}), 6.46(\mathrm{~d}, J=8.0 \mathrm{~Hz}, 2 \mathrm{H})$, $5.90(\mathrm{~d}, J=8 \mathrm{~Hz}, 2 \mathrm{H}), 4.38$ (bs, 4H), 1.23 (s, 36H). ${ }^{13} \mathrm{C}$ NMR $(100$ $\left.\mathrm{MHz}, \mathrm{CDCl}_{3}\right): \delta 154.65,154.61,154.39,153.92,151.01,150.98$, 139.33, 139.25, 139.16, 138.16, 121.24, 121.01, 103.68, 103.14, 102.86, 99.75, 97.56, 47.33, 34.78, 31.43. FAB-MS: $881\left[\mathrm{M}^{+}\right]$. Anal. Calcd for $\mathrm{C}_{55} \mathrm{H}_{67} \mathrm{~N}_{11}$ : C, 74.87; H, 7.66; N, 17.47. Found: C, 74.06; H, 7.62; $\mathrm{N}, 16.96$

$\mathrm{N}$-(3',5'-Di-tert-butylbenzyl)pyridine-2,6-diamine (9). To a mixture of 2,6-diaminopyridine $(1.09 \mathrm{~g}, 0.01 \mathrm{~mol})$ and $\mathrm{KO}-\mathrm{tBu}(2.24 \mathrm{~g}, 0.02$ mol) in dry benzene $(30 \mathrm{~mL})$ was added a solution 3,5-di-tertbutylbenzylbromide $(2.83 \mathrm{~g}, 0.01 \mathrm{~mol})$ in benzene $(5 \mathrm{~mL})$ at room temperature with constant stirring. The mixture was refluxed at $80{ }^{\circ} \mathrm{C}$ for $6 \mathrm{~h}$. After cooling, the crude mixture was quenched with saturated solution of $\mathrm{NH}_{4} \mathrm{Cl}(4 \mathrm{~mL})$, washed with water $(4 \mathrm{~mL})$, and dried over anhydrous $\mathrm{MgSO}_{4}$. The solvent was removed, and the crude product was chromatographed over silica gel (hexane/EtOAc, 3:1) to give 9 $(2.36 \mathrm{~g}, 76 \%)$ as a light brown thick liquid. $R_{f} 0.32$ (hexane/EtOAc, 4:1). IR (KBr): 3476, 3380, 3302, $1609 \mathrm{~cm}^{-1}$. ${ }^{1} \mathrm{H}$ NMR $(400 \mathrm{MHz}$, $\left.\mathrm{CDCl}_{3}\right): 7.44(\mathrm{t}, J=1.6 \mathrm{~Hz}, 1 \mathrm{H}), 7.23-7.30(\mathrm{~m}, 3 \mathrm{H}), 5.85-5.88(\mathrm{~m}$, $2 \mathrm{H}), 4.96(\mathrm{t}, J=5.6 \mathrm{~Hz}, 1 \mathrm{H}), 4.18-4.20(\mathrm{~m}, 4 \mathrm{H}), 1.41(2,18 \mathrm{H}) .{ }^{13} \mathrm{C}$ NMR (100 MHz, $\left.\mathrm{CDCl}_{3}\right): 31.29,34.59,47.03,95.16,96.79,120.88$, 121.65, 138.15, 139.12, 150.71, 157.57, 158.12. MS: $\mathrm{m} / \mathrm{z}(\mathrm{EI} 70 \mathrm{eV})$ $311\left(\mathrm{M}^{+}, 100\right)$. Anal. Calcd for $\mathrm{C}_{20} \mathrm{H}_{29} \mathrm{~N}_{3}$ : C, 77.11; H, 9.39; N, 13.50 . Found: C, 76.83; H, 9.29; N, 13.34. 
Preparation of $N^{2}, N^{6}$-Dibenzylpyridine-2,6-diamine (2) and 2- $N$ Benzylamino-6-bromopyridine (10). To a magnetically stirred solution of 2,6-dibromopyridine (2.37 g, $0.01 \mathrm{~mol})$, KO- $t \mathrm{Bu}(1.40 \mathrm{~g}, 0.0125$ $\mathrm{mol}), \mathrm{Pd}_{2}(\mathrm{dba})_{3}(0.025 \mathrm{mg}, 0.25 \mathrm{~mol} \%)$, and BINAP (30 mg, $0.5 \mathrm{~mol}$ $\%)$ in dry benzene $(40 \mathrm{~mL})$ was added benzylamine $(1.09 \mathrm{~mL}, 0.01$ mol) dropwise at room temperature under argon atmosphere. The reaction mixture was refluxed at $80{ }^{\circ} \mathrm{C}$ for $4 \mathrm{~h}$. After cooling, the reaction mixture was quenched with saturated $\mathrm{NH}_{4} \mathrm{Cl}$ solution (4 mL), washed with $\mathrm{H}_{2} \mathrm{O}(4 \mathrm{~mL})$, and dried over anhydrous $\mathrm{MgSO}_{4}$. The solvent was removed under vacuum, and purification by column chromatography over silica gel (hexane/EtOAc, 19:1) gave 2-benzylamino-6-bromopyridine (10) (575 $\mathrm{mg}, 22 \%)$ as colorless crystals. $R_{f} 0.47$ (hexane/EtOAc, 9:1). mp $88{ }^{\circ} \mathrm{C}$. IR (KBr): 3288, 3084, 1606, $1566 \mathrm{~cm}^{-1} .{ }^{1} \mathrm{H}$ NMR (200 MHz, DMSO- $\left.d_{6}\right): 7.45(\mathrm{t}$, $J=6 \mathrm{~Hz}, 1 \mathrm{H}, \mathrm{NH}), 7.19-7.32(\mathrm{~m}, 6 \mathrm{H}), 6.63(\mathrm{~d}, J=8 \mathrm{~Hz}, 1 \mathrm{H})$, $6.46(\mathrm{~d}, J=8 \mathrm{~Hz}, 1 \mathrm{H}), 4.40(\mathrm{~d}, J=6.0 \mathrm{~Hz}, 2 \mathrm{H}) .{ }^{13} \mathrm{C}$ NMR $(100$ MHz, DMSO- $\left.d_{6}\right)$ : 44.24, 98.61, 126.32, 127.03, 128.06, 137.86, 140.96, 153.16, 157.38. MS: $m / z(\mathrm{EI}, 70 \mathrm{eV}) 264\left(\mathrm{M}^{+}+2\right), 262\left(\mathrm{M}^{+}\right)$. HRMS $\left(\mathrm{M}^{+}\right)$calcd for $\mathrm{C}_{12} \mathrm{H}_{11}{ }^{79} \mathrm{BrN}_{2}, 262.0105$; found, 262.0099. Also gave $N^{2}, N^{6}$-dibenzylpyridine-2,6-diamine (2) (490 mg, 17\%) as colorless crystals. $R_{f} 0.7$ (hexane/EtOAc, 4:1). ${ }^{1} \mathrm{H}$ NMR $(400 \mathrm{MHz}$, $\left.\mathrm{CDCl}_{3}\right): \delta 7.41-7.23(\mathrm{~m}, 11 \mathrm{H}), 5.78(\mathrm{~d}, J=8 \mathrm{~Hz}, 2 \mathrm{H}), 4.84(\mathrm{t}, J=$ $5.6 \mathrm{~Hz}, 2 \mathrm{H}, \mathrm{NH}), 4.48(\mathrm{~d}, J=5.6 \mathrm{~Hz}, 4 \mathrm{H}) .{ }^{13} \mathrm{C} \mathrm{NMR}(100 \mathrm{MHz}$, $\left.\mathrm{CDCl}_{3}\right): \delta 157.91,139.69,138.93,128.34,127.25,126.82,95.00$, 46.11 .

Preparation of $N$-(6'-Bromopyrid-2'-yl)pyridine-2,6-diamine (11) and $N^{2}, N^{6}$-Bis $\left(6^{\prime}\right.$-bromopyrid-2'-yl)pyridine-2,6-diamine (12). To a mixture of 2,6-diaminopyridine $(1 \mathrm{~g}, 0.009 \mathrm{~mol})$ and 2,6-dibromopyridine $(2.17 \mathrm{~g}, 0.009 \mathrm{~mol})$ in dry benzene $(10 \mathrm{~mL})$ was added $\mathrm{KO}-t \mathrm{Bu}$ $(2.06 \mathrm{~g}, 0.018 \mathrm{~mol})$ at room temperature under $\mathrm{N}_{2}$ atmosphere with constant stirring. The reaction mixture was refluxed at $80^{\circ} \mathrm{C}$ for $16 \mathrm{~h}$. After cooling, the crude mixture was quenched with saturated $\mathrm{NH}_{4} \mathrm{Cl}$ solution $(2 \mathrm{~mL})$, washed with $\mathrm{H}_{2} \mathrm{O}(2 \mathrm{~mL})$, and dried over anhydrous $\mathrm{MgSO}_{4}$. The solvent was removed under vacuum, and the product was recrystallized from $\mathrm{CH}_{2} \mathrm{Cl}_{2}$ to give $N^{2}, N^{6}$-bis(6'-bromopyrid-2'-yl)pyridine-2,6-diamine $(\mathbf{1 2})(310 \mathrm{mg}, 8 \%)$ as a brown solid. $R_{f} 0.68$ $\left(\mathrm{CH}_{2} \mathrm{Cl}_{2}\right)$. IR (KBr): 3262, 3256, 3089, 3067, 3031, $1556 \mathrm{~cm}^{-1} .{ }^{1} \mathrm{H}$ NMR (200 MHz, DMSO- $\left.d_{6}\right): 7.03(\mathrm{~d}, J=8.0 \mathrm{~Hz}, 2 \mathrm{H}), 7.04$ (d, $J=$ $8.0 \mathrm{~Hz}, 2 \mathrm{H}), 7.57(\mathrm{t}, J=7.8 \mathrm{~Hz}, 2 \mathrm{H}), 7.58(\mathrm{t}, J=7.9 \mathrm{~Hz}, 2 \mathrm{H}), 7.84$ $(\mathrm{d}, J=8.2 \mathrm{~Hz}, 1 \mathrm{H}), 9.84$ (s, 2H). ${ }^{13} \mathrm{C}$ NMR $\left(100 \mathrm{MHz}, \mathrm{DMSO}-d_{6}\right)$ : 103.9, 110.4, 118.6, 138.4, 139.2, 140.4, 151.8, 154.2. FAB-MS: $\mathrm{m} / \mathrm{z}$ $419\left(\mathrm{M}^{+}\right)$. Anal. Calcd for $\mathrm{C}_{15} \mathrm{H}_{11} \mathrm{~N}_{5} \mathrm{Br}_{2}$ : C, 42.79; $\mathrm{H}, 2.63 ; \mathrm{N}, 16.63$. Found: C, 42.98; H, 2.67; N, 16.43. The remaining crude mixture was purified by column chromatography over silica gel $\left(\mathrm{CH}_{2} \mathrm{Cl}_{2}\right)$ to give $N$-(6'-bromopyrid-2'-yl)pyridine-2,6-diamine (11) $(1.36 \mathrm{~g}, 56 \%)$ as a light brown solid. $R_{f} 0.24\left(\mathrm{CH}_{2} \mathrm{Cl}_{2}\right)$. IR ( $\left.\mathrm{KBr}\right): 3443,3305,3198,1633$, $1570 \mathrm{~cm}^{-1} .{ }^{1} \mathrm{H}$ NMR (200 MHz, DMSO- $\left.d_{6}\right): 5.76$ (bs, 2H), 5.98 (d, $J$ $=7.0 \mathrm{~Hz}, 1 \mathrm{H}), 6.55(\mathrm{~d}, J=7.8 \mathrm{~Hz}, 1 \mathrm{H}), 6.96(\mathrm{~d}, J=7.6 \mathrm{~Hz}, 1 \mathrm{H})$, $7.25(\mathrm{t}, J=7.8 \mathrm{~Hz}, 1 \mathrm{H}), 7.49(\mathrm{t}, J=8.0 \mathrm{~Hz}, 2 \mathrm{H}), 8.03(\mathrm{~d}, J=8.3 \mathrm{~Hz}$, $1 \mathrm{H}), 9.53(\mathrm{~s}, 1 \mathrm{H}) .{ }^{13} \mathrm{C}$ NMR (100 MHz, DMSO- $\left.d_{6}\right)$ : 98.9, 99.8, 110.2, 117.9, 138.3, 138.5, 140.1, 152.4, 154.7, 158.2. FAB-MS: $m / z 264$ $\left(\mathrm{M}^{+}\right)$. Anal. Calcd for $\mathrm{C}_{10} \mathrm{H}_{9} \mathrm{~N}_{4} \mathrm{Br}$ : C, 45.45; H, 3.44; N, 21.22. Found: C, 45.55; H, 3.47; N, 20.72.

$N$-(6'-Bromo-2'-pyridyl)- $N^{\prime}$-(6"'- $N$-benzylamino-2"'-pyridyl)-2,6diaminopyridine (13). To a magnetically stirred solution of $2-\mathrm{N}$ benzylamino-6-bromopyridine (10) (524 mg, $2 \mathrm{mmol})$ and $\mathrm{N}$-(6'bromopyrid-2'-yl)pyridine-2,6-diamine (11) $(264 \mathrm{mg}, 1 \mathrm{mmol})$ in dry benzene $(20 \mathrm{~mL})$ were added $\mathrm{KO}-\mathrm{Bu}(280 \mathrm{mg}, 2.5 \mathrm{mmol}), \mathrm{Pd}_{2}(\mathrm{dba})_{3}$ (21 mg, 2 mol \%), BINAP (25 mg, $4 \mathrm{~mol} \%$ ), and 18-crown-6 (528 $\mathrm{mg}, 2 \mathrm{mmol}$ ) at room temperature under argon atmosphere. The stirring was continued at $80{ }^{\circ} \mathrm{C}$ for $4 \mathrm{~h}$. After cooling, the reaction mixture was quenched with saturated $\mathrm{NH}_{4} \mathrm{Cl}$ solution $(4 \mathrm{~mL})$, washed with $\mathrm{H}_{2} \mathrm{O}$ (4 $\mathrm{mL}$ ), and dried over anhydrous $\mathrm{MgSO}_{4}$. The crude mixture was purified over silica gel to yield $\mathbf{1 3}(170 \mathrm{mg}, 38 \%)$ as colorless crystals. $R_{f} 0.62$ (hexane:EtOAc, 7:3). mp $168^{\circ} \mathrm{C}$. IR (KBr): 3288, 3192, 3020, 1603, $1582 \mathrm{~cm}^{-1} .{ }^{1} \mathrm{H}$ NMR (300 MHz, DMSO- $\left.d_{6}\right)$ : $9.72(\mathrm{~s}, 1 \mathrm{H}, \mathrm{NH})$, $8.90(\mathrm{~s}, 1 \mathrm{H}, \mathrm{NH}), 8.17(\mathrm{~d}, J=8.1 \mathrm{~Hz}, 1 \mathrm{H}), 7.54(\mathrm{t}, J=7.8 \mathrm{~Hz}, 1 \mathrm{H})$, $7.17-7.41(\mathrm{~m}, 8 \mathrm{H}), 7.01(\mathrm{~d}, J=7.5 \mathrm{~Hz}, 1 \mathrm{H}), 6.90(\mathrm{t}, J=6.0 \mathrm{~Hz}, 1 \mathrm{H}$, $\mathrm{NH}), 6.76(\mathrm{dd}, J=6.1$ and $2.2 \mathrm{~Hz}, 1 \mathrm{H}), 6.58(\mathrm{~d}, J=7.8 \mathrm{~Hz}, 1 \mathrm{H})$, $6.00(\mathrm{~d}, J=8.1 \mathrm{~Hz}, 1 \mathrm{H}), 4.48(\mathrm{~d}, J=6.0 \mathrm{~Hz}, 2 \mathrm{H}) .{ }^{13} \mathrm{C}$ NMR $(100$ MHz, DMSO- $d_{6}$ ): 44.40, 98.65, 98.96, 102.89, 103.55, 110.45, 118.46, 126.42, 127.03, 128.16, 138.11, 138.45, 138.68, 140.38, 140.91, 151.97, 152.60, 153.12, 154.49, 157.52. FAB-MS: $m / z 448\left(\mathrm{M}^{+}+2\right), 446$ $\left(\mathrm{M}^{+}\right)$. Anal. Calcd for $\mathrm{C}_{22} \mathrm{H}_{19} \mathrm{BrN}_{6}$ : C, 59.07; H, 4.28; N, 18.79 . Found: C, 58.54; H, 4.24; N, 18.52 .

4.3. Methods. ${ }^{1} \mathrm{H}$ and ${ }^{13} \mathrm{C}$ NMR were recorded in $\mathrm{CDCl}_{3}$ or DMSO$d_{6}$, and chemical shifts were reported in ppm relative to $\mathrm{CHCl}_{3}(\delta 7.24$ ppm for ${ }^{1} \mathrm{H}$ and $77.0 \mathrm{ppm}$ for $\left.{ }^{13} \mathrm{C}\right)$ or DMSO- $d_{6}\left(\delta 2.49 \mathrm{ppm}\right.$ for ${ }^{1} \mathrm{H}$ and $39.5 \mathrm{ppm}$ for ${ }^{13} \mathrm{C}$ ). Melting points were uncorrected. The variableconcentration ${ }^{1} \mathrm{H}$ NMR measurements $(400 \mathrm{MHz}$ ) for $\mathbf{2}, \mathbf{3}, \mathbf{5}, \mathbf{6}$, and 7 were run in $\mathrm{CDCl}_{3}$, using the signal of $\mathrm{CHCl}_{3}(\delta=7.25)$ as the internal standard. Before use, $\mathrm{CDCl}_{3}$ was treated with $\mathrm{K}_{2} \mathrm{CO}_{3}$ to remove any acidic impurity, dried over molecular sieves $4 \mathrm{~A}$, and distilled. Experimental details for the concentration-dependent chemical shifts are provided in the Supporting Information.

For the electrospray ionization mass spectroscopy (ESI-MS), a Finnigan LCQ quadruple ion trap mass spectrometer equipped with a pneumatically assisted electrospray ionization source was used. The mass spectrometer was operated in the positive ion mode by applying a voltage of $4.5 \mathrm{kV}$ to the ESI needle. The temperature of the heated capillary in the ESI source was set at $200{ }^{\circ} \mathrm{C}$. To avoid a space charge effect, the number of ions present in the trap at one time was regulated by automatic gain control, which was set at $5 \times 10^{7}$ ions for the fullmass target. The flow rate of the sheath gas of nitrogen was set at 30 units. Helium was used as the damping gas at a pressure of $10^{-3}$ Torr. Voltage across the capillary and the octapole lenses was tuned by an automated procedure to maximize signals from the ion of interest in the mass spectrum.

Steady-state absorption and emission spectra were recorded by a U-3310 (Hitachi) spectrophotometer and a F4500 (Hitachi) fluorimeter, respectively. The sample compartment of U-3310A was attached by a temperature-controlled unit so that temperature variation studies can be performed within -10 to $80^{\circ} \mathrm{C}$. Because the titration experiment is critical for interpretation of the hydrogen-bonding association, we have carefully performed our absorption and fluorescence titration studies where each piece of data was acquired from an average of three to five measurements. The sensitivity for the absorption measurement is approximately $1.5 \times 10^{-4}$ in absorbance under constant temperature $\left( \pm 0.1^{\circ} \mathrm{C}\right)$ throughout the measurement.

$\mathrm{Ab}$ initio calculation was carried out using Gaussian $98 .{ }^{36}$ Geometry optimization and frequency analyses were carried out at the HF/6-31G* level. All stationary points were verified by performing vibrational analyses. Dimerization energies reported were results of single point calculations of $\Delta E_{\text {dimer }}=E_{\text {dimer }}-2 E_{\text {monomer }}$, with counterpoise corrections for basis set superposition errors (BSSE), at the B3LYP ${ }^{37,38} / 6$ $31+\mathrm{G}^{* *}$ level.

For the crystal structure determinations, data collection was carried out on a Siemens SMART diffractometer with a CCD detector (Mo $\mathrm{K} \alpha$ radiation, $\lambda=0.71073 \AA$ ) at room temperature. A preliminary

(36) Frisch, M. J.; Trucks, G. W.; Schlegel, H. B.; Scuseria, G. E.; Robb, M. A.; Cheeseman, J. R.; Zakrzewski, V. G.; Montgomery, J. A., Jr.; Stratmann, R. E.; Burant, J. C.; Dapprich, S.; Millam, J. M.; Daniels, A. D.; Kudin, K. N.; Strain, M. C.; Farkas, O.; Tomasi, J.; Barone, V.; Cossi, M.; Cammi, R.; Mennucci, B.; Pomelli, C.; Adamo, C.; Clifford, S.; Ochterski, J.; Petersson, G. A.; Ayala, P. Y.; Cui, Q.; Morokuma, K.; Malick, D. K.; Rabuck, A. D.; Raghavachari, K.; Foresman, J. B.; Cioslowski, J.; Ortiz, J. V.; Stefanov, B. B.; Liu, G.; Liashenko, A.; Piskorz, P.; Komaromi, I.; Gomperts, R.; Martin, R. L.; Fox, D. J.; Keith, T.; Al-Laham, M. A.; Peng, C. Y.; Nanayakkara, A.; Gonzalez, C.; Challacombe, M.; Gill, P. M. W.; Johnson, B. G.; Chen, W.; Wong, M. W.; Andres, J. L.; Head-Gordon, M.; Replogle, E. S.; Pople, J. A. Gaussian 98, revision A.7; Gaussian, Inc.: Pittsburgh, PA, 1998

(37) Becke, A. D. J. Chem. Phys. 1993, 98, 5648

(38) (a) Lee, C., Yang, W.; Parr, R. G. Phys. Rev. B 1988, 37, 785. (b) Miehlich, B.; Savin, A.; Stoll, H.; Preuss, H. Chem. Phys. Lett. 1989, 157, 200. 
orientation matrix and unit cell parameters were determined from three runs of 15 frames each, each frame corresponding to $0.3^{\circ}$ scan in $20 \mathrm{~s}$, followed by spot integration and least-squares refinement. For each structure, data were measured using $\omega$ scans of $0.3^{\circ}$ per frame for 20 $\mathrm{s}$ until a complete hemisphere had been collected. Cell parameters were retrieved using SMART ${ }^{39}$ software and refined with SAINT on all observed reflections. Data reduction was performed with the SAINT ${ }^{40}$ software and corrected for Lorentz and polarization effects. Absorption corrections were applied with the program SADABS. ${ }^{40}$ The structures of $\mathbf{2 a}, \mathbf{2 b}, \mathbf{3}$, and $\mathbf{4}$ are solved by direct methods with the SHELX-93 ${ }^{41}$ program and refined by full-matrix least-squares methods on $F^{2}$ with SHEXLTL-PC V 5.03. ${ }^{42}$ All non-hydrogen atomic positions were located in difference Fourier maps and refined anisotropically. Hydrogen atoms attached to nitrogen atoms were located and refined isotropically. The rest of the hydrogen atoms attached to carbon atoms were fixed at calculated positions and refined using a riding mode. Detailed crystal data of $\mathbf{2 a}, \mathbf{2 b}, \mathbf{3}$, and $\mathbf{4}$ are listed in Table 1, and the bond lengths and angles are deposited in the Supporting Information (CIF files).

Crystal Data of 2a. Single crystals of $\mathbf{2}$ were obtained by recrystallization from hexanes/ethyl acetate. A light-yellow crystal of approximate dimensions $0.4 \times 0.4 \times 0.25 \mathrm{~mm}^{3}$ was mounted on a glass capillary. A total of 17886 reflections was collected with a final resolution of $0.75 \AA$. Sadabs absorption correction $\left(T_{\min } 0.819\right.$ and $T_{\max }$ $0.928)$ and 4217 unique reflections $\left(2 \theta<50^{\circ}, R_{\text {int }}=0.0867\right)$ were used in the refinement. Full-matrix least-squares refinement on $F^{2}$ converged to $R_{\mathrm{F}}=0.0763[I>2 \sigma(I)], 0.1479$ (all data) and $R_{\mathrm{w}}\left(F^{2}\right)=$ $0.1785[I>2 \sigma(I)], 0.2195$ (all data).

Crystal Data of 2b. A light-yellow crystal of approximate dimensions $0.60 \times 0.12 \times 0.06 \mathrm{~mm}^{3}$ was mounted on a glass capillary. A total of 6396 reflections was collected with a final resolution of 0.75 $\AA$. Sadabs absorption correction $\left(T_{\min } 0.783\right.$ and $\left.T_{\max } 0.928\right)$ and 4529 unique reflections $\left(2 \theta<50^{\circ}, R_{\text {int }}=0.0412\right)$ were used in the refinement. Full-matrix least-squares refinement on $F^{2}$ converged to $R_{\mathrm{F}}=0.0583[I>2 \sigma(I)], 0.0912$ (all data) and $R_{\mathrm{w}}\left(F^{2}\right)=0.1067[I>$ $2 \sigma(I)], 0.1236$ (all data)

Crystal Data of 3. Single crystals of $\mathbf{3}$ were obtained by recrystallization from hexanes/ethyl acetate. A light-yellow crystal of approximate dimensions $0.40 \times 0.20 \times 0.05 \mathrm{~mm}^{3}$ was mounted on a glass capillary. A total of 25990 reflections was collected with a final resolution of $0.75 \AA$. Sadabs absorption correction $\left(T_{\min } 0.675\right.$ and $T_{\max }$ $0.928)$ and 7296 unique reflections $\left(2 \theta<50^{\circ}, R_{\text {int }}=0.0590\right)$ were used in the refinement. Full-matrix least-squares refinement on $F^{2}$ converged to $R_{\mathrm{F}}=0.0611[I>2 \sigma(I)], 0.1349$ (all data) and $R_{\mathrm{w}}\left(F^{2}\right)=$ $0.1188[I>2 \sigma(I)], 0.1500$ (all data).

Crystal Data of 4 . Single crystals of $\mathbf{4}$ were obtained by recrystallization from hexanes/ethyl acetate. A light-yellow crystal of approximate dimensions $0.20 \times 0.15 \times 0.10 \mathrm{~mm}^{3}$ was mounted on a glass capillary. A total of 25402 reflections was collected with a final resolution of $0.75 \AA$. Sadabs absorption correction $\left(T_{\min } 0.796\right.$ and $T_{\max }$ $0.928)$ and 4346 unique reflections $\left(2 \theta<50^{\circ}, R_{\text {int }}=0.0917\right)$ were used in the refinement. Full-matrix least-squares refinement on $F^{2}$ converged to $R_{\mathrm{F}}=0.0796[I>2 \sigma(I)], 0.1338$ (all data) and $R_{\mathrm{w}}\left(F^{2}\right)=$ $0.1410[I>2 \sigma(I)], 0.1658$ (all data)

Acknowledgment. We thank the National Science Council and the Ministry of Education of the Republic of China for financial support.

(39) SMART V 4.043 Software for the CCD Detector System; Siemens Analytical Instruments Division: Madison, WI, 1995

(40) SAINT V 4.045 Software for the CCD Detector System; Siemens Analytical Instruments Division: Madison, WI, 1995.

(41) Sheldrick, G. M. SHELXL-93, Program for the Refinement of Crystal Structure; University of Göttingen: Göttingen, Germany, 1993.

(42) SHELXTL 5.03 (PC-Version), Program Library for Structure Solution and Molecular Graphics; Siemens Analytical Instruments Division: Madison, WI, 1995.

\section{Appendix}

Derivation of Eq 2. A competitive equilibrium between monomer and dimer of oligo- $\alpha$-aminopyridines (OAP) can be depicted as $2(\mathrm{OAP}) \rightleftharpoons(\mathrm{OAP})_{2}$, and the dimerization constant $K_{\mathrm{d}}$ for the formation of the OAP dimer can be expressed as

$$
K_{\mathrm{d}}=\frac{C_{\mathrm{p}}}{\left(C_{0}-2 C_{\mathrm{p}}\right)^{2}}
$$

where $C_{0}$ is the initial concentration of OAP, and $C_{\mathrm{p}}$ denotes the concentration of the OAP dimeric form. The rearrangement of eq a leads to

$$
\frac{C_{0}}{C_{\mathrm{p}}}=\sqrt{\frac{1}{K_{\mathrm{d}} C_{\mathrm{p}}}}+2
$$

Under equilibrium the absorbance $A$ at any selected wavelength can be expressed as

$$
\begin{gathered}
A=\epsilon_{\mathrm{D}} C_{\mathrm{p}} l+\epsilon_{\mathrm{M}}\left(C_{0}-2 C_{\mathrm{p}}\right) l=\left(\epsilon_{\mathrm{D}}-2 \epsilon_{\mathrm{M}}\right) C_{\mathrm{p}} l+C_{0} \epsilon_{\mathrm{M}} l \\
\therefore C_{\mathrm{p}}=\frac{A-C_{0} \epsilon_{\mathrm{M}} l}{\left(\epsilon_{\mathrm{D}}-2 \epsilon_{\mathrm{M}}\right) l}
\end{gathered}
$$

where $l$ is the cell length, and $\epsilon_{\mathrm{M}}$ and $\epsilon_{\mathrm{D}}$ denote the molar extinction coefficient of monomer and dimer, respectively. Combining eqs $\mathrm{b}$ and $\mathrm{c}$, one obtains

$$
\frac{C_{0} l\left(\epsilon_{\mathrm{D}}-2 \epsilon_{\mathrm{M}}\right)}{A-C_{0} \epsilon_{\mathrm{M}} l}=\sqrt{\frac{\left(\epsilon_{\mathrm{D}}-2 \epsilon_{\mathrm{M}}\right) l}{K_{\mathrm{d}}\left(A-C_{0} \epsilon_{\mathrm{M}} l\right)}}+2
$$

Dividing $\left(\epsilon_{\mathrm{D}}-2 \epsilon_{\mathrm{M}}\right)$ on each side leads to eq e.

$\frac{C_{0} l}{A-C_{0} \epsilon_{\mathrm{M}} l}=\sqrt{\frac{l}{K_{\mathrm{d}}\left(\epsilon_{\mathrm{D}}-2 \epsilon_{\mathrm{M}}\right)}} \sqrt{\frac{1}{\left(A-C_{0} \epsilon_{\mathrm{M}} l\right)}}+\frac{2}{\epsilon_{\mathrm{D}}-2 \epsilon_{\mathrm{M}}}$

By multiplying $\epsilon_{\mathrm{M}}$ on each side and applying the Beer-Lambert law, eq e can be rewritten to obtain eq 2

$\frac{A_{0}}{A-A_{0}}=\sqrt{\frac{l \epsilon_{\mathrm{M}}^{2}}{K_{\mathrm{d}}\left(\epsilon_{\mathrm{D}}-2 \epsilon_{\mathrm{M}}\right)}} \sqrt{\frac{1}{\left(A-C_{0} \epsilon_{\mathrm{M}} l\right)}}+\frac{2 \epsilon_{\mathrm{M}}}{\epsilon_{\mathrm{D}}-2 \epsilon_{\mathrm{M}}}$

where $A_{0}$ in eq 2 simply denotes the absorbance of the monomer assuming that no dimer is formed at the prepared concentration. $\epsilon_{\mathrm{M}}$ can be derived by performing the concentration-dependent study at a sufficiently low concentration so that only monomer mainly exists. By knowing the proportionality of the dilution, $A_{0}$ values can thus be obtained in each prepared concentration. Knowing $\epsilon_{\mathrm{M}}$ at the analyzed wavelength, $K_{\mathrm{d}}$ can be deduced by intercept $/(\text { slope })^{2}=2 K_{\mathrm{d}} / l \epsilon_{\mathrm{M}}$.

Supporting Information Available: CIF files containing detailed crystal data of $\mathbf{2 a}, \mathbf{2 b}, \mathbf{3}$, and $\mathbf{4}$. Original ${ }^{1} \mathrm{H}$ and ${ }^{13} \mathrm{C}$ NMR spectra of 2-9 and 10-13. Experimental details for the NH's chemical shifts collected from the concentration-dependent experiments (PDF). These materials are available free of charge via the Internet at http://pubs.acs.org.

JA011679P 